\title{
Alleviation of salinity stress in plants by endophytic plant-fungal symbiosis: Current knowledge, perspectives and future directions
}

\author{
Sneha Gupta • Martino Schillaci • Robert Walker • \\ Penelope M. C. Smith • Michelle Watt • Ute Roessner
}

Received: 11 February 2020 / Accepted: 22 June 2020 / Published online: 9 July 2020

(C) The Author(s) 2020

\begin{abstract}
Salinization of soil with sodium chloride ions inhibits plant functions, causing reduction of yield of crops. Salt tolerant microorganisms have been studied to enhance crop growth under salinity. This review describes the performance of endophytic fungi applied to crops as a supplement to plant genetics or soil management to alleviate salt stress in crops. This is achieved via inducing systemic resistance, increasing the levels of beneficial metabolites, activating antioxidant systems to scavenge ROS, and modulating plant growth phytohormones. Colonization by endophytic fungi improves nutrient uptake and maintains ionic homeostasis by modulating ion accumulation, thereby restricting the transport of $\mathrm{Na}^{+}$to leaves and ensuring a low cytosolic $\mathrm{Na}^{+}: \mathrm{K}^{+}$ratio in plants. Participating endophytic fungi enhance transcripts of genes encoding the high Affinity Potassium Transporter 1 (HKT1) and the inwardrectifying $\mathrm{K}^{+}$channels KAT1 and KAT2, which play key roles in regulating $\mathrm{Na}^{+}$and $\mathrm{K}^{+}$homeostasis. Endophytic-induced interplay of strigolactones play regulatory roles in salt tolerance by interacting with
\end{abstract}

Responsible Editor: Boris Rewald

S. Gupta $(\bowtie) \cdot$ M. Schillaci $\cdot$ R. Walker $\cdot$ M. Watt •

U. Roessner

School of BioSciences, University of Melbourne, Parkville, VIC, Australia

e-mail: snehagupta14@gmail.com

P. M. C. Smith

Centre for AgriBiosciences, Department of Animal, Plant and Soil Sciences, School of Life Sciences, La Trobe University,

Bundoora, VIC, Australia phytohormones. Future research requires further attention on the biochemical, molecular and genetic mechanisms crucial for salt stress resistance requires further attention for future research. Furthermore, to design strategies for sustained plant health with endophytic fungi, a new wave of exploration of plant-endophyte responses to combinations of stresses is mandatory.

Keywords Endophytic fungi - Biochemical changes · Ionic homeostasis · Osmoregulation · Hormones · Salinity · Roots · Soil · Inoculants · Microorganisms

\section{Soil salinity affects agriculture globally}

The beginning of the 21st century has been marked by global scarcity of water resources, increased environmental pollution and salinization of soil and fresh water. Two major threats for agricultural sustainability are increased human population and reduction in arable land available for crop cultivation (Shahbaz and Ashraf 2013). Several environmental stresses such as high winds, extreme temperatures, drought, salinity and flood have impacted on the production and cultivation of agricultural crops. Among these, soil salinity is one of the most significant environmental stresses resulting in major reductions in cultivatable land area, and decreased crop productivity and quality. It is estimated that $50 \%$ of all arable land will be impacted by salinity by 2050 (Shrivastava and Kumar 2015) and that globally, soil salinity results in more than US\$12 billion in annual losses due to reduced crop productivity (Jägermeyr and 
Frieler 2018). Salinity is recognized as the main threat to environmental resources in several countries, affecting almost 1 billion ha worldwide, which represents about $7 \%$ of the earth's continental area (Shrivastava and Kumar 2015). Consequently, it is important to understand the crop responses to this major soil and plant stress to minimize economic loss and improve food security.

Soil is defined as being saline when the electrical conductivity (EC) of the saturation extract (ECe) in the root zone exceeds $4 \mathrm{dSm}^{-1}$ at $25^{\circ} \mathrm{C}$ and has an exchangeable sodium of $15 \%(\mathrm{w} / \mathrm{v})$. Salinization also includes excessive accumulation of ions such as calcium $\left(\mathrm{Ca}^{2+}\right)$, magnesium $\left(\mathrm{Mg}^{2+}\right)$, sodium $\left(\mathrm{Na}^{+}\right)$, sulphates $\left(\mathrm{SO}_{4}{ }^{2-}\right)$, and chlorides $\left(\mathrm{Cl}^{-}\right)$in the soil, inhibiting plant growth and cellular functions. The most abundant ion in most salt-affected soils is $\mathrm{Na}^{+}$and hence the exchange phase is dominated by $\mathrm{Na}^{+}$. A secondary process often associated with saline soils is alkalinisation, creating a condition known as sodicity. This results in the degradation of soil physical properties and porosity, leading to reduced water and air flow and increased soil hardness and crusting.

Apart from affecting soil physical properties, high soil salinity directly and adversely affects plants- both native vegetation and introduced crops, severely affecting seed germination, root growth, and the physiological functions of crops (Oster and Jayawardane 1998). It has been estimated that worldwide $20 \%$ of total cultivated and $33 \%$ of irrigated agricultural land is affected by high salinity. This is mainly due to the toxicity of the salt ions directly on the plant cells but also through general osmotic effects of the soil around the roots of the plant. High osmotic potentials at the soil-root interface reduce the ability of the plant to absorb water from the soil (Machado and Serralheiro 2017).

Native plants have evolved mechanisms to tolerate low rainfall and high salinity over hundreds of thousands of years (Steffen et al. 2009). However, in the past 200 years, human activities have intensely disrupted the natural hydrological balance in many regions of the globe. This has resulted in significant consequences for the distribution of salt in all landscapes leading to severe degradation of both natural and agricultural environments. It is predicted that the total area of land affected by salinity will increase drastically over the next few decades if effective solutions are not implemented. These solutions would involve significant changes to our present systems of management including research and development of strategies to improve salt tolerance in crops and improve mechanisms to mitigate its consequences (Rengasamy 2002, 2006).

\section{Effects of salt stress on above-ground and below-ground organs of plants}

Plants have two major systems, the above-ground organs (shoots) and below-ground organs (roots). Each system has morphological, physiological and anatomical differences that affect plant performance differently (Gregory 2007). However, while these two systems grow and function as a separate site for the uptake of nutrients and other resources, they are coupled, and their functions need to form an integrated system. The aboveground system is highly dependent on the development of below-ground organs and without a sufficiently developed root system, the above-ground system cannot fully mature (de Willigen and van Noordwijk 1987).

Salinity limits vegetative and reproductive development by inducing physiological dysfunctions, and this has profound implications on different harvested organs such as leaf, stem, root, shoot, fruit or grain. The complex phenomenon of tolerance and response to salt stress involves dynamic changes in growth, physiology, metabolic pathways and gene expressions (Atkinson and Urwin 2012; Munns and Tester 2008). Strategies used to mitigate against salt stress include proline accumulation within cells (Matysik et al. 2002), modulation of hormones and accumulation of glycine betaine and polyols (Gupta and Huang 2014). They also involve generation of nitric oxide (NO) and compounds to combat formation of reactive oxygen species (ROS). NO directly or indirectly triggers expression of several redox-regulated genes. NO also reacts with lipid radicals thus preventing lipid oxidation, exerting a protective effect by scavenging superoxide radicals and formation of peroxynitrite that can be neutralised by other cellular processes. NO also helps in the activation of many antioxidant enzymes including catalase (CAT), ascorbate or thiol-dependent peroxidases (APX), glutathione reductases (GR) and superoxide dismutase (SOD).

The effect of salinity on leaf growth, biomass production and grain yield on several crops are well documented (Hasanuzzaman et al. 2013; Munns et al. 2011; Munns and Tester 2008; Sun et al. 2014). The extent to which plants are damaged by salinity depends on several 
factors including species, genotype, plant growth phase, ionic strength, duration of salinity exposure, composition of salinizing solution and, most importantly, which plant organ is exposed (Robin et al. 2016).

Munns (2005) hypothesized that salinity damage in plants occurs in two temporal phases. The first phase of growth reduction occurs rapidly after exposure and is due to an osmotic effect, while the second phase, which is a slower process, is due to the accumulation of salt ions, mainly in older leaves. Early symptoms of the second phase of growth reduction include damage to old leaves and a reduced photosynthetic capacity (Munns et al. 2006). At the plant organ level, shoots have been demonstrated to be more sensitive to salinity than roots (Munns and Tester 2008). However, roots are exposed to salinity stress before leaves and can respond rapidly through changes in elongation (Rahnama et al. 2011) and function (Shelden et al. 2016). The roots are crucial for a myriad of physiological processes including water and nutrient uptake, preventing toxic substances from reaching photosynthetic tissue, signal exchange with shoots, anchoring of plants, and providing mechanical support to the above-ground organs.

\section{The root-soil interface/ The rhizosphere}

Roots and their growing substrate are intrinsically connected, and they mutually influence each other at all stages of plant life (Gregory 2006). The interface between roots and the soil is a complex and often illdefined zone. Compounds are released from roots into the surrounding soil matrix resulting in changes to its chemical and physical properties. The narrow zone of soil that surrounds and is influenced by plant roots is known as the rhizosphere. The term rhizosphere was first defined over a century ago by Hiltner (1904) and recently, redefined by Pinton et al. (2007) as the most dynamic interface on earth that includes soil influenced by the root, along with the root tissues. The rhizosphere is home to a vast number of microorganisms (Morgan et al. 2005; Pinton et al. 2007), and consists of three distinct zones: (a) the endorhizosphere, which includes part of the cortex and endodermis in which microbes occupy the apoplastic space; (b) the rhizoplane, which is the medial zone immediately next to the root consisting of the root surface and mucilages; and (c) the ectorhizosphere, which extends from the rhizoplane out into the bulk soil (Lynch 1990).
The root system architecture is greatly influenced by soil conditions (Rich and Watt 2013), including nutrient gradients and concentrations of nitrate and phosphorus (Ho et al. 2005; Paterson et al. 2006). Roots also affect the surrounding nutrient composition by the release of organic compounds that play a vital role in mineralizing nutrients. The compounds released from the roots into the surrounding soil are generally part of rhizodeposits (Jones et al. 2009), which include a range of substances from sloughed-off root cells and tissues, mucilages, volatiles, and soluble lysates and exudates from damaged and intact cells (Curl and Truelove 1986; Dakora and Phillips 2002; Watt 2009). Abiotic factors influence the root system (Bekkara et al. 1998; Brimecombe et al. 2000; Groleau-Renaud et al. 1998; Watt and Evans 1999) with roots responding by secreting a different combination of compounds to protect against negative effects and encourage positive microbial interactions (Badri and Vivanco 2009). These secreted compounds usually induce an interactive metabolic cross-talk involving diverse biosynthetic networks and pathways.

Root exudates include both secretions (including mucilage) that are actively released from the root and diffusates which are passively released because of osmotic differences between soil solution and the root cells (McNear 2013). Inorganic root exudates include ions, water, ubiquitous $\mathrm{H}^{+}$and electrons. Although the concentration of inorganic compounds make up far less of the root exudate composition compared to organic compounds but their role is still significant (Khorassani 2008; Uren 2000). Organic compounds can be classified into high molecular weight compounds, such as complex molecules including polysaccharides secreted by root cap cells and epidermal cells at the apical zone, and low molecular weight compounds that include arabinose, fructose, glucose, amino acids, organic acids, plant hormones and phenolic compounds (Bertin et al. 2003). Due to the richness of inorganic and organic compounds in rhizodeposits, the rhizosphere is home to specialised microbes that are able to utilise these compounds as an energy source.

Several recent and comprehensive reviews have been written covering the diversity and activity of microorganisms at within roots and in the rhizosphere, as well as the functions and effects of microorganisms in nutrient turnover and supply to the plant (Garcia et al. 2016; Jacoby et al. 2017; Smith and Smith 2011; Udvardi and Poole 2013). In the following section, the use of microorganisms as one of the key approaches used to alleviate 
abiotic stresses, with the focus on using fungi as a major beneficial microbe will be discussed.

\section{Alleviating salt stress by association with endophytic fungi}

Diverse metabolic and genetic strategies used by plantassociated microbes can reduce the impact of salt stress and other abiotic stresses arising from extreme environmental conditions (Gopalakrishnan et al. 2015; Singh 2014). Induced Systemic Tolerance (IST) is the term used to describe microbe-mediated induction of abiotic stress responses (Meena et al. 2017). In these beneficial situations, rhizosphere microorganisms not only perceive and respond to signal molecules secreted by plant roots, they also release diverse signalling molecules that influence plants, resulting in increased biotic and abiotic stress resistance or tolerance, as well as root development and plant growth (Zhang et al. 2017a). Microbial interactions with plants induce several local and systemic responses that improve the metabolic capacity of plants to respond to salt stress (Nguyen et al. 2016). This microorganisms-based plant biotechnology has proven to be more efficient in many cases than plant breeding and genetic modification approaches (Smith 2014).

Beneficial effects due to plant root interactions with endophytic fungi

In recent years the ability of mycorrhizal fungi to induce tolerance against salt stress in crops has been documented (Gangwar and Singh 2018) (Fig. 1). In a mycorrhizal association, the fungus colonizes the host plant's root tissues, either intracellularly as in arbuscular mycorrhizal fungi (AMF), or forms extracellular exchange mechanisms outside of the root cells, as in ectomycorrhizal fungi. Thus, mycorrhiza fungi can be categorised as endo- inside plant tissue, or ecto- associated with the external rhizosphere or not penetrating root cells. For the purpose of clarity, this review will only focus on endomycorrhizal (termed as endophytic for this review) fungi.

Penetration and colonisation of plant roots appears to be essential for some endophytic fungal strains that are reported to promote plant growth and provide protection against pathogens. For example, some species belonging to the genus Trichoderma can colonize local sites (Metcalf and Wilson 2001) on roots, mediated by hydrophobins- (Viterbo et al. 2004) and expansin-like proteins (Brotman et al. 2008) present in the outermost cell wall layer that coats the fungal cell surface. Other rhizosphere-competent Trichoderma spp. colonize entire root surfaces for long periods of time (Harman 2000; Thrane et al. 1997) or penetrate the epidermis and the cortex (Yedidia et al. 1999). Once hyphae penetrate roots, a series of fungal bioactive compounds can be produced inducing plant biochemical mechanisms (Harman 2006). The callose-enriched wall appositions in the root cell limit the growth of the Trichoderma spp. to a small area (epidermis and cortex), preventing the entry of Trichoderma spp. into the vascular stele (Hermosa et al. 2012; Yedidia et al. 1999). Arbuscular mycorrhiza fungi (AMF) are another group of endophytic fungi. Their hyphae penetrate plant cells, producing structures that are either balloon-like (vesicles) or dichotomously branching invaginations (arbuscules) as a means of nutrient exchange. The fungal hyphae do not in fact penetrate the protoplast (i.e. the interior of the cell), but invaginate the cell membrane. Dark septate endophytic (DSE) fungi are also root endophytes, characterized by intense dark pigmentation and the formation of septate and melanized hyphae and occasionally microsclerotia (Knapp et al. 2015; Yuan et al. 2016). They can be found in plant cortical cells inter- and intracellularly and are present in several environments (Li et al. 2019; Santos et al. 2017). In contrast to the vast information on AMF, information on the role of DSE fungi in the ecosystem is limited.

Colonization of several crops with endophytic fungi has been reported to induce systemic resistance to pathogens, mitigate stress by increasing the levels of protective metabolites and osmoprotectants, activate antioxidant systems to prevent damage caused by ROS, decreasing salt induced root respiration and modulate the phytohormone profile to minimize salt effects on growth of plants (Ghaffari et al. 2016; Jogawat et al. 2013; Li et al. 2017; Nia et al. 2012; Rewald et al. 2015; Zhang et al. 2019a). These effects are in coordinated to improve plant growth and resilience to salinity stress. These ameliorative effects can be evaluated in terms of improved plant growth exhibited by endophyte colonized (ENC) plants in comparison to non-endophytic (NENC) colonized plants.

Salinity triggers a decrease in stomatal conductance, thus decreasing the $\mathrm{CO}_{2}: \mathrm{O}_{2}$ ratio and increasing photorespiration (Kangasjärvi et al. 2012). This causes an increase in stomatal resistance to transpiration and an 
Non-endophytic colonized plant- salinity

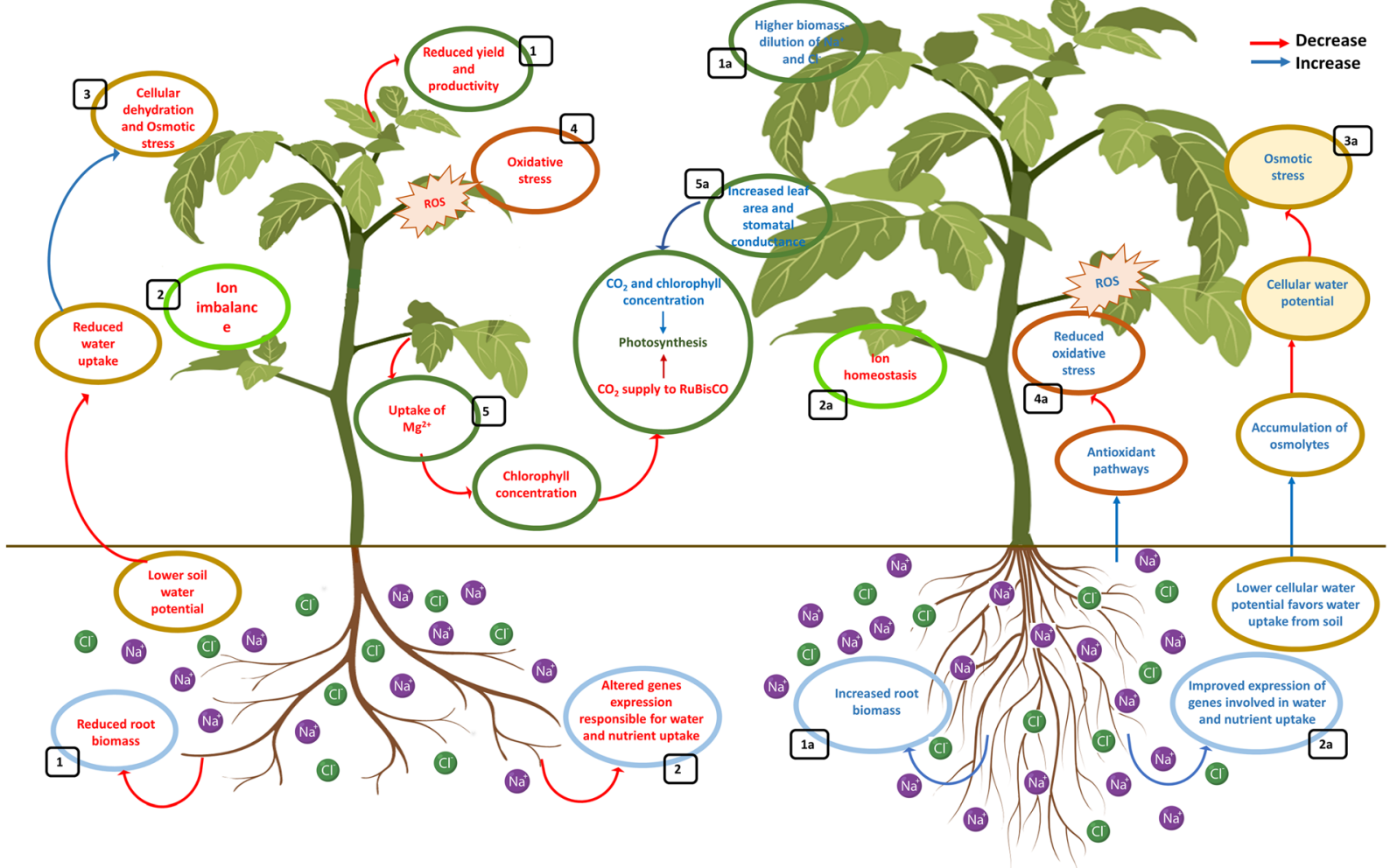

Fig. 1 Potential beneficial effects of root colonisation of plants by endophytic, symbiotic fungi in saline soil conditions, summarised from the literature. Salinity results in reduced root biomass due to salt-induced inhibition of cell division and affect the total biomass yield (1) (left). Plant colonized with endophytic fungi improves biomass accumulation by modifying root architecture and increased nutrient absorption (1a) (right). Salt accumulation creates competition for nutrient uptake and transport. This results in imbalance of the ionic composition of plant, affecting plant's physiological traits (2) (left). Endophytic fungi improve expression of genes and upregulate several cation transporters, resulting in improved nutrient uptake and maintenance of ionic homeostasis (2a) (right). Increase of salt in soil lowers soil water potential

increase in the rate of tissue respiration. Under these conditions, photosynthetic capacity is limited, and the plant uses its own photo-assimilates, resulting in decreased growth. Rewald et al. (2015) showed that in NENC Ulmus glabra seedlings there was a significant increase in fine root respiration under salt stress as compared to their ENC counterparts. This suggested that colonization by endophytic fungi can prevent a major increase of root respiration under moderate $\mathrm{NaCl}$ stress, enabling trees to deploy more assimilated $\mathrm{C}$ for growth and, theoretically, improve defence mechanisms against other stress factors occurring in urban environments. resulting in cellular dehydration (3) (left). Endophytic fungi negate this effect by mediating accumulation of osmolytes consequently improving plant's water status (3a) (right). Increasing salinity causes oxidative stress due to imbalance in reactive oxygen species generation and quenching activities of antioxidants (4) (left). Endophytic fungi improve the antioxidant systems of plants reducing oxidative stress under salt stress (4a) (right). Salt stress hinders photosynthesis by reducing uptake of magnesium and decreasing chlorophyll concentration which eventually reduces carbon dioxide supply to RuBisCo (5) (left). Endophytes have a positive effect on photosynthesis under salt stress (5a) (right). See text for relevant references and further details

Endophytic fungi are effective against several root diseases (Azcón-Aguilar and Barea 1997; Borowicz 2001) and impart stress tolerance to plants (Duc et al. 2018; Evelin et al. 2019; Yasmeen et al. 2019), but can also enhance susceptibility to biotrophic leaf pathogens (Gernns et al. 2001; Waller et al. 2005). These endophytes have been frequently reported to not only protect against plant pathogens and pests but also impart strong tolerance against several abiotic stresses in crops (Gangwar and Singh 2018).

In the past decade, significant progress has been made to understand several mechanisms of salt tolerance imparted by endophytic fungi. In the following sections, 
current understanding of biochemical and physiological changes that occur in salt stressed plants inoculated with endophytic fungi will be covered. This will include advances made recently toward better understanding of the mechanisms that contribute to salt stress alleviation in ENC plants. Finally, gaps in our understanding of the mechanisms will be identified and research challenges to be met in future studies will be discussed.

\section{Mechanisms of salt tolerance in ENC plants}

Increase in total biomass

Total biomass is usually evaluated as an indicator of the plant's ability to tolerate salinity. Several studies have highlighted that endophytic fungi impart salinity tolerance in host plants by virtue of higher biomass as compared to NENC plants. Endophytic fungus colonization has been demonstrated to increase biomass in Zea mays L. (Rho et al. 2018), soybean (Hamayun et al. 2017), Vochysia divergens Pohl (Farias et al. 2019), Solanum lycopersicum (Azad and Kaminskyj 2016), Brassica juncea (Ahmad et al. 2015), Oryza sativa L. (Saddique et al. 2018) and, Triticum aestivum L. (Zhang et al. 2019b).

The total biomass can also be assessed by measuring plant relative growth rate (plant weight increment per plant weight unit). This includes measurement of the net assimilation rate (NAR) (the increase in plant weight per leaf area unit), the leaf area ratio (LAR) and root relative growth rate $\left(\mathrm{RGR}_{\text {plant }}\right)$. Balliu et al. (2015) investigated the effects of commercially available AMF inoculant (Glomus sp. mixture) on growth and nutrient acquisition in tomato (Solanum lycopersicum L.) plants grown in media with different levels of salinity. Salinity stress immediately and significantly reduced the LAR, NAR and $\mathrm{RGR}_{\text {plant }}$ in NENC as compared to ENC plants. Similarly, Sallaku et al. (2019) showed that AMF alleviates the salinity stress in cucumber plants by extending their root length and root surface area and even more through enhancing their photosynthetic rate (NAR) as compared to NENC plants.

\section{Alteration of root architecture}

Root branching and root system architecture play a significant role in determining the composition of exudates (Badri and Vivanco 2009). Changes in the root system architecture for regulating salt acquisition and translocation are crucial for enhancing plant resistance to salt stress (Jung and McCouch 2013). Barley plants experienced a decline in primary root growth under saline conditions due to salt-induced inhibition of cell division and elongation of root epidermal cells, while simultaneously stimulating lateral root development (Rahnama et al. 2011). Endophytic fungi can modulate the plant's ability to modify root architecture (SalopeSondi et al. 2015; Vahabi et al. 2016). Yun et al. (2018) observed that the length and volume of roots were greater in ENC than in NENC maize plants under saline conditions and similar observations have been reported in Hordeum vulgare (Waller et al. 2005) and Oryza sativa L. (Kord et al. 2019). Improved root systems enable the plant to utilize water and minerals from non-saline areas until exploitation of areas affected by salt cannot be avoided (Jogawat et al. 2013). Though few studies have shown the ability of endophytic fungi to alter root architecture under saline conditions for beneficial purposes, much remains to be investigated on endophytic fungi influenced root architecture for better water and nutrient uptake in saline conditions.

\section{Osmoregulation}

Upon exposure to saline environments, plants undergo a reduction in water absorbing capacity from the soil, disrupting cell water relations and inhibiting cell expansion. In order to negate these effects, plants employ osmoregulation as a mechanism to tolerate salt stress (Munns and Tester 2008). This is achieved by accumulation of osmolytes in the form of proline, glycine betaine, sugars, organic acids, polyamines and amino acids contributing to osmotic adjustment (Hasegawa et al. 2000). These osmolytes, often termed as compatible solutes, are organic compounds of low molecular weight that are water soluble and non-toxic at high concentrations (Chen and Murata 2011).

Under salt stress, ENC plants have been shown to possess higher osmotic potential than NENC plants (Contreras-Cornejo et al. 2014) due to accumulation of osmolytes (Ahmad et al. 2015; Song et al. 2015) (Fig. 2). Osmolytes are also involved in quenching reactive oxygen species (ROS), maintaining membrane integrity, and stabilizing enzymes. Osmolytes are also described as osmoprotectants (Azad and Kaminskyj 2016; Li et al. 2017). Endophytic symbiosis can influence the concentration and profile of polyamines and organic acids in plants (Chen et al. 2019; Zhao et al. 


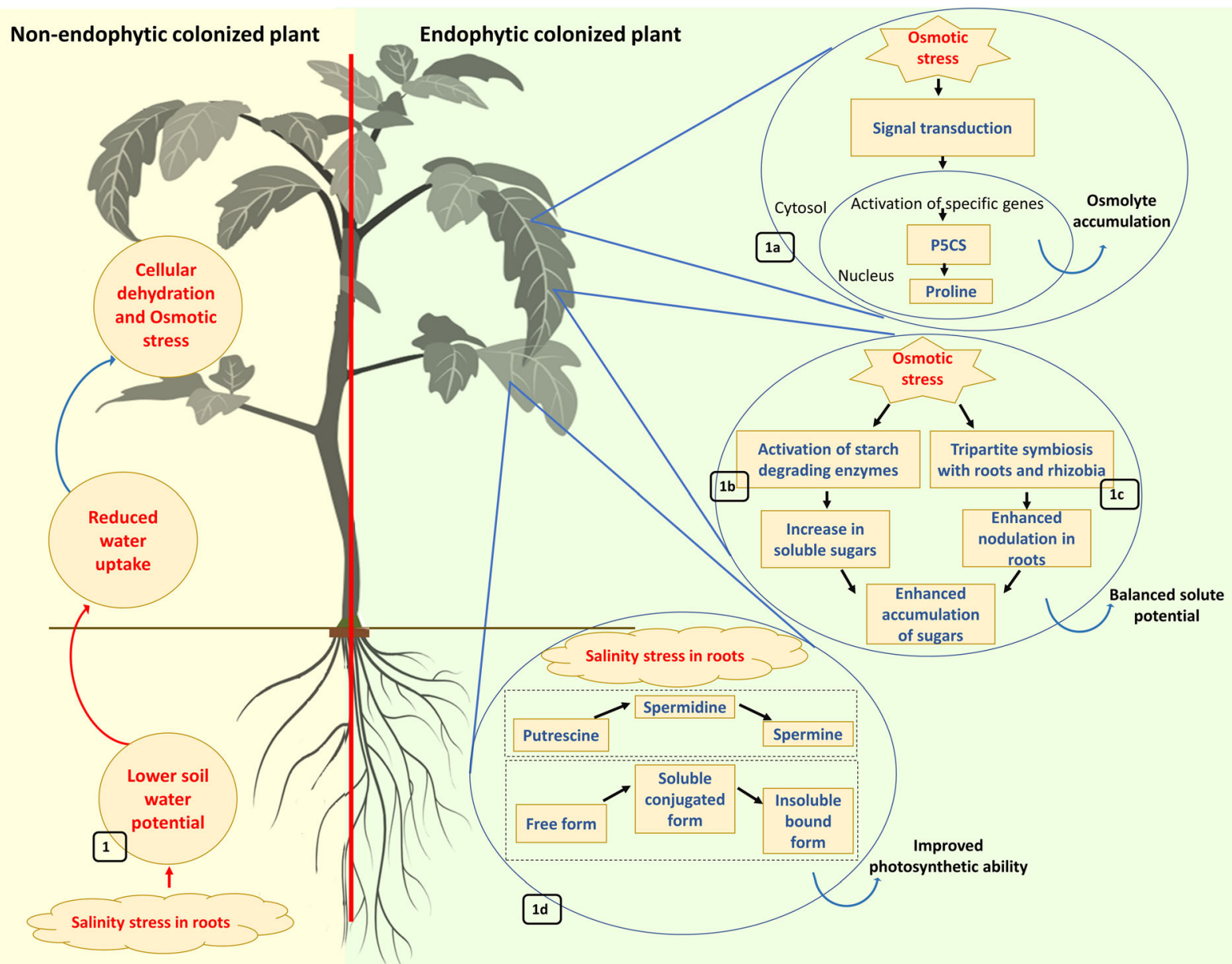

Fig. 2 Salinity stress induced osmotic stress tolerance mechanisms in plants. Increase in salt in soil lowers the soil water potential of plant cells. This reduces water uptake by plants and consequently causes cellular dehydration (1) (left). To combat this issue, plants accumulate osmolytes, such as proline, sugars and polyamines in higher concentration. Osmolyte accumulation results in lowering of cellular water potential and maintains a favourable gradient for water uptake from soil to roots. Endophytic

2014). Polyamines help retain ion homeostasis in plant cells by enhancing the uptake of nutrients and water (Pang et al. 2007). Organic acids may increase the availability of nitrogen, phosphorus and potassium $(\mathrm{N}$, $P$ and K) in soil (Samolski et al. 2012). The role of specific osmolytes in improving salt tolerance is ENC plants are discussed below.

\section{Proline}

Proline is one of the most common osmoprotectants that accumulates in plants during salt stress, thereby fungi alleviate osmotic stress by influencing the expression of specific genes, P5CS, pyroline-5-carboxylate synthase (1a) (right), involved in the biosynthesis of the osmolyte proline, activation of starch degrading enzyme, glucan-water dikinase (1b) (right) and forming tripartite symbiosis with roots and rhizobia (1c) (right) to elevate the accumulation of sugars and by increasing the biosynthesis of polyamines such as spermidine and spermine (1D) (right). See text for relevant references and further details

ameliorating the negative effects of salinity. Proline has been observed to protect cell walls under osmotic stress, protect protein integrity and to increase enzymatic activity by acting as a molecular chaperone. Proline also has a role in scavenging ROS and shows singlet oxygen quenching ability (Kaur and Asthir 2015). Despite these benefits, there are conflicting reports on the role of endophytic fungi in proline accumulation in salt stressed plants. Several studies reported increases in proline contents in ENC plants compared to NENC plants, while others have reported lower proline contents in ENC plants (Table 1). Higher proline content in ENC 


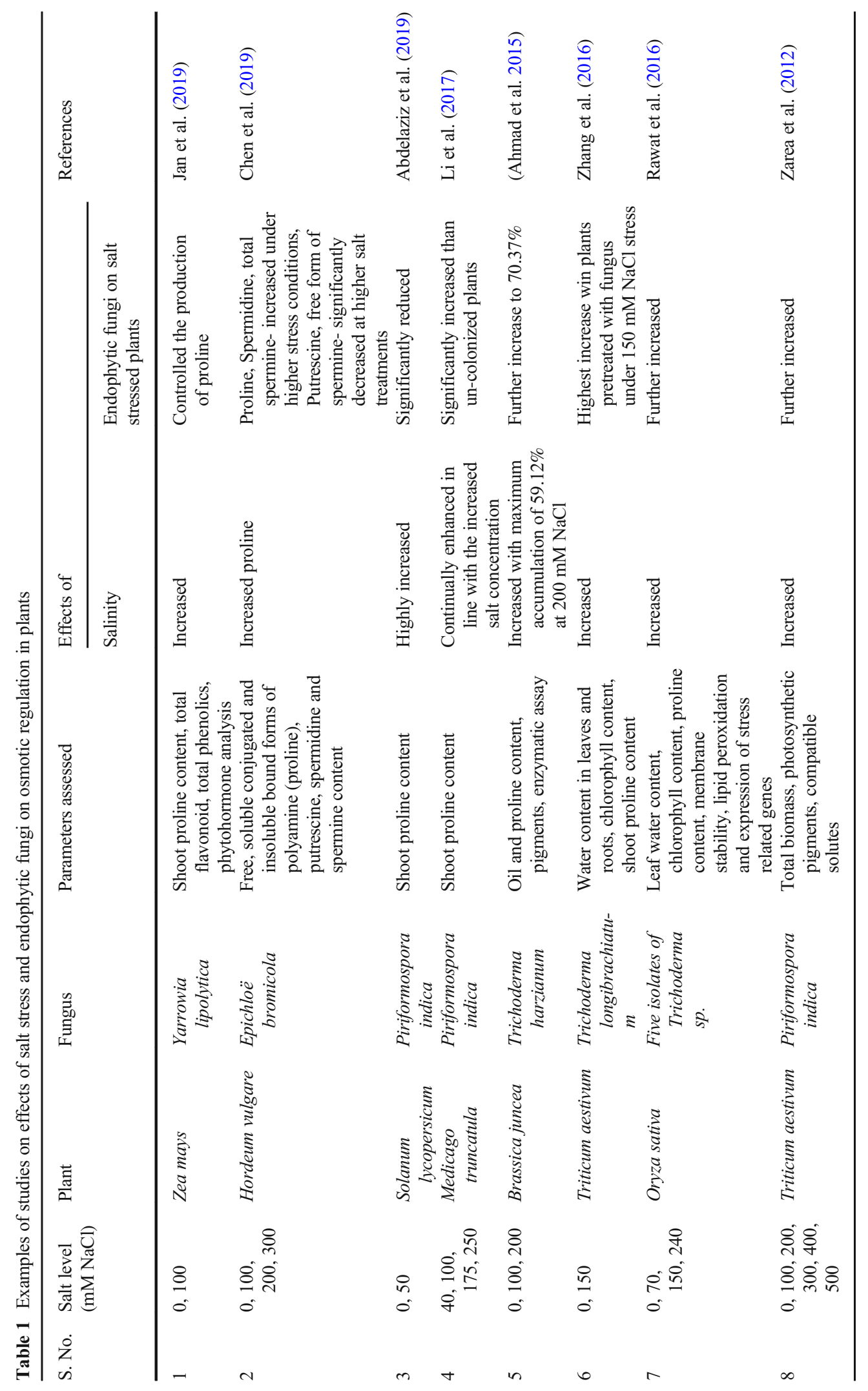


plants has been attributed to - (i) favouring a decline in ionic influx inside cellular masses thus helping plants to maintain their osmotic balance; (ii) increasing the expression of the gene encoding Pyrroline-5-carboxylate synthase (P5CS) enzyme which is involved in proline biosynthesis; and (iii) increasing activity of the P5CS enzyme (Rawat et al. 2016). Besides its role as an osmolyte proline can act as a stress marker. In ENC tomato plants, proline accumulation was reduced when the toxic effects of salinity were reduced following colonization of an endophytic fungus, Piriformospora indica (Abdelaziz et al. 2019).

\section{Sugars}

In salt stressed plants, the accumulation of total soluble sugars, such as glucose, sucrose, dextrins and maltose, serves as an osmoprotection as they can stabilize the cell membrane and protoplast. These sugars also protect water soluble enzymes from high intracellular concentrations of inorganic ions (Liang et al. 2018). The synthesis of soluble sugars from starch and sucrose in plants is upregulated by the activities of sucrose anabolizing enzymes such as $\alpha$ - and $\beta$-amylase, which convert starch into dextrins and maltose, respectively (Preiss 2018). Sucrose phosphate synthase and sucrose synthase catalyse the synthesis of sucrose, while $\beta$ fructofuranosidase catalyses the breakdown of sucrose to glucose and fructose (Peng et al. 2016). In plants grown under saline conditions, sucrose undergoes decomposition in order to meet the requirements for glucose (Munns and Tester 2008).

There have been reports that show the role of endophytic fungi in enhancing accumulation of soluble sugars in salt stressed plants (Qi and Zhao 2013; Uma Shaanker 2014; Zhang et al. 2019b). These sugars act as chemoattractant signals to soil rhizobia (el Zahar Haichar et al. 2014). These chemoattractants can direct movement to microorganisms in response to chemical gradients- a behaviour known as chemotaxis. This chemotactic response of microorganisms to root exudates play key role in initiating communication between plant roots and microbes. Yang et al. (2015) reported that the colonization by Phomopsis liquidambari could stimulate sugar secretion from the rhizodeposition of sloughed off cells and root debris of rice, thereby providing carbon to the endophytic fungi. Another study of $P$. liquidambari on peanut showed increased soluble sugar contents in leaves. This was due to the ability of the fungus to form tripartite symbiotic associations with peanut roots and rhizobia. This tripartite association significantly enhanced peanut nodulation (Zhang et al. 2017b). Here, sucrose derived from photosynthesis was transported to bacterial inoculated root nodules and was hydrolysed by sucrose synthase into UDP-glucose and fructose. This was due to the allocation of more carbon by the endophyte toward peanut and rhizobia symbionts by increased soluble sugar content, leading to more active nodule carbon metabolism in ENC plants.

Furthermore, Sherameti et al. (2005) also suggested that one of the major starch-degrading enzymes, glucanwater dikinase, activated by the fungus in colonized roots, is responsible for the increase in soluble sugars in ENC plants. Similar results were obtained by Ghabooli (2014) with Piriformospora indica increasing the level of soluble sugars, including glucose, fructose, and sucrose, in inoculated plants under salt stress conditions. Recently, Zhang et al. (2019a) demonstrated that $T$. harzianum improved salt tolerance of cucumber seedlings by enhancing accumulation of sugars. This results in adjustment of the osmotic potential for cellular water retention and turgor maintenance, thereby minimizing the adverse effects of salt stress by balancing the solute potential (Bai et al. 2019).

\section{Organic acids}

Other important osmolytes in plants are organic acids such as citric acid and malic acid. They are found in plant vacuoles and the regulation of their metabolism plays a crucial role in providing tolerance to salt stress (Guo et al. 2010). Fungal endophytes have been reported to induce the release of organic compounds by the roots (Yang et al. 2015; Zhang et al. 2014), thus influencing the concentrations and profile of organic acids in plants. One of the major plant nutritional disorders associated with increased salinity in soil is iron $(\mathrm{Fe})$ deficiency. Endophytes can enhance Fe acquisition by their host through their ability to secrete organic acids which chelate and solubilise iron in the soil (Chen et al. 1998; Khan et al. 2006). A study by Zhao et al. (2014) demonstrated that the release of organic acids from endophytes, resulted in ferric solubilization to form organic ferric salts that can be assimilated directly by plants under saline conditions. It has also been shown that ENC plants have better nutrient uptake capacity and distribution within plant tissues due to modulation of the root architecture and nutrient availability in the soil. 
These benefits are imparted by increases in organic acids produced by ENC plants (Samolski et al. 2012; Zhao et al. 2014). Limited research has been done on understanding the mechanisms underlying the changes in organic acids in ENC plants, thus this topic calls for further investigation.

\section{Polyamines}

Polyamines (PA) are low molecular weight nitrogenous aliphatic molecules that participate in physiological processes such as activation of antioxidant systems, cell growth and development, and in cellular osmoregulation in plants under salt stress (Singh et al. 2018). PA also regulate ion channels, either by direct binding or via PA-induced signalling molecules (ROS and NO). PAs also regulate the activity of ion channels indirectly by membrane depolarization. The hyperpolarizationactivated $\mathrm{Ca}^{2+}$ influx and the NO-induced release of intracellular $\mathrm{Ca}^{2+}$ result in a higher cytoplasmic $\mathrm{Ca}^{2+}$ concentration, which is a major component in general stress responses such as stomatal movements (Wani 2018; Williams 1997). They are either present in free, soluble conjugated (covalently conjugated with small molecules such as phenolic acids) or insoluble (bound with macromolecules such as proteins, DNA and RNA) forms. These compatible solutes accumulate under salt stress and include putrescine (Put, diamine), spermidine (Spd, triamine) and spermine (Spm, tetramine) (Minocha et al. 2014; Todorova et al. 2013).

Differences in PA (Put, Spd, Spm) responses under salt-stress have been reported in several species (Singh et al. 2018) and it remains unclear which polyamine plays the major role in imparting salt tolerance. Chen et al. (2019) demonstrated that the putrescine content was significantly reduced in ENC plants compared to NENC plants in high stress conditions whereas spermidine and spermine content showed the opposite pattern. It was suggested that salinity stress tolerance induced by endophytic fungus Epichloë bromicola correlated with enhanced conversion of putrescine to spermidine and spermine. The fungus also converted the free forms and soluble conjugated forms of polyamines to insoluble bound forms of polyamines.

Modulation of the polyamine pool to help tolerate salt stress by arbuscular mycorrhizal fungi (AMF) is well explored (Evelin et al. 2009). However, research on polyamine metabolism during the interactions between endophytic fungi and plants under salt stress is underrepresented and many questions remain unanswered. For example, most plant polyamine research relates to changes in free polyamines, and where polyamine conjugates have been measured, substantial changes have been detected. The precise role of polyamines, free or conjugated, in ENC plants remains unclear. Further investigations, focusing on understanding endophyte-facilitated modulation of polyamines, including the intracellular localization of free polyamines and conjugates associated with salt tolerance in plants, is needed. Already some of the key genes involved in the biosynthetic pathways have been cloned making it possible to manipulate polyamine metabolism using molecular genetic approaches (Malmberg et al. 1998). Hence, genetic manipulation of polyamine levels in ENC plants may allow valuable insights into the role of these compounds especially in studies of plant tolerance to salt stress.

Nutrient acquisition and ionic homeostasis

High salt $\left(\mathrm{Na}^{+}\right.$and $\left.\mathrm{Cl}^{-}\right)$in the soil disturbs nutrient availability by imposing competition during uptake, translocation or distribution within the plant. This may suppress nutrient associated activities resulting in undesired ratios of $\mathrm{Na}^{+}: \mathrm{K}^{+}, \mathrm{Na}^{+}: \mathrm{Ca}^{2+}$, and $\mathrm{Ca}^{2+}: \mathrm{Mg}^{2+}$ (Munns et al. 2011). This in turn results in imbalance among ionic composition of the plant subsequently affecting plants physiological traits (Hasegawa et al. 2000; Munns et al. 2006). However, endophytic symbiosis has been shown to improve assimilation of nutrients and assist in maintenance of ionic homeostasis in host plants grown in saline conditions (Table 2).

Although the effects of AM fungi on plant nutrient acquisition are commonly discussed based on the differences of nutrient concentration in plant tissues, the relative uptake rate of nutrient elements (RUR) has recently been suggested as a better tool to distinguish the differences among treatments over a short period, as the nutrient concentration could be largely influenced by the dilution effect of fast growth in young plants. Balliu et al. (2015) found that RUR values of ENC tomato plants grown in both non-saline and moderate saline conditions were higher than in non-inoculated seedlings. Similarly, another study showed the enhancement effect of AMF inoculation on the nutrient uptake capacity of cucumber seedlings after salt stress (Sallaku et al. 2019). 


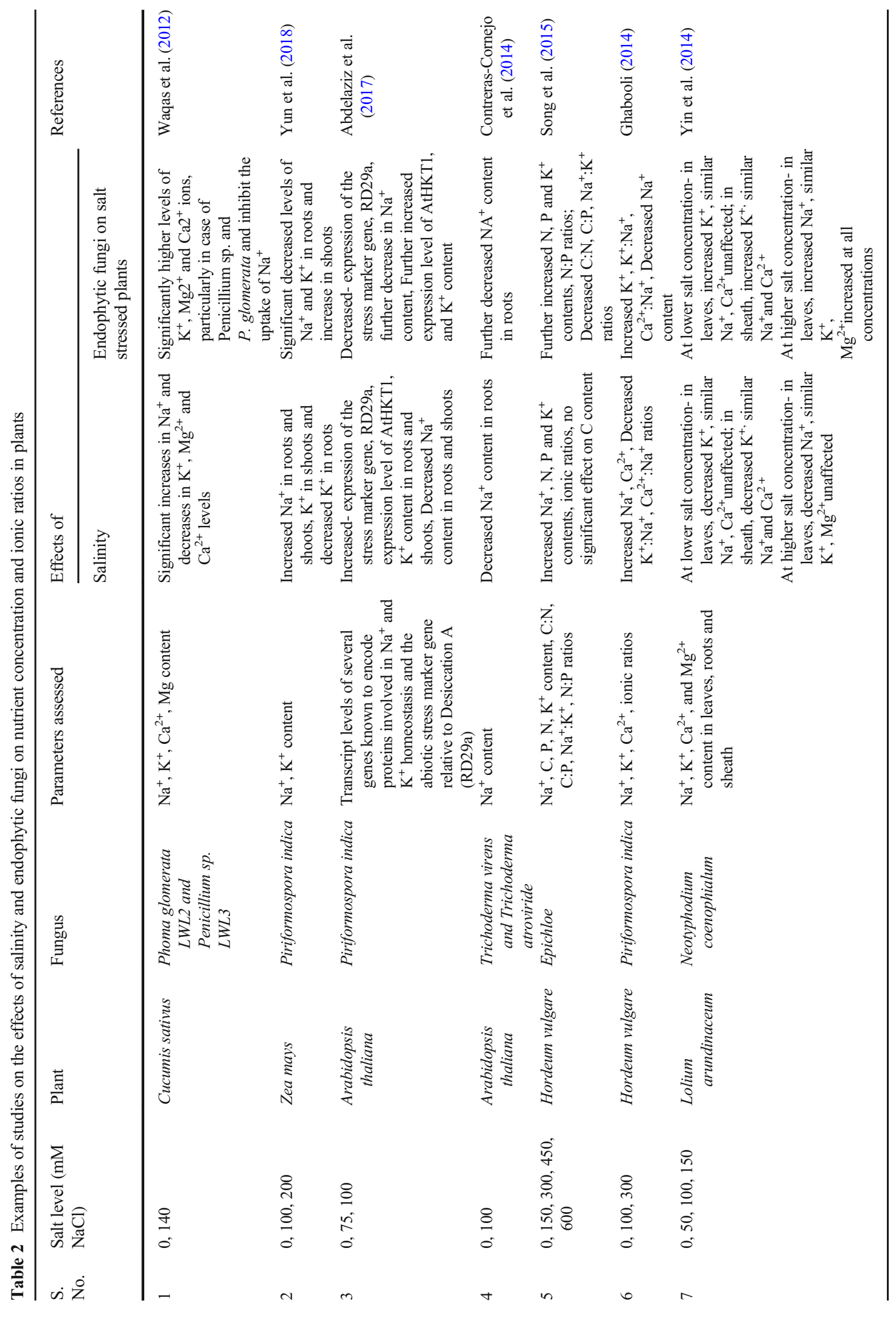




\section{Phosphorus}

Phosphorus $(\mathrm{P})$ and nitrogen $(\mathrm{N})$ are two of the most important and essential elements for plant growth with crucial roles in cell function and metabolism (Uchida 2000). Increased salt in soil occludes $P$ to plants due to its precipitation with other cations (de Aguilar et al. 1979), thereby creating soil-induced $P$ deficiency in plants. This affects the normal growth of the plant and causes older leaves to die prematurely (Niu et al. 2012). Increased $\mathrm{P}$ acquisition in ENC plants under saline conditions is attributed to (i) increased availability of phosphates in soil due to the conversion of insoluble phosphates into soluble forms through the process of acidification, chelation and exchange reactions; (ii) ability of endophytic fungi to absorb $\mathrm{P}$ at lower thresholds owing to the expression of a high affinity Pi transporter, PiPT, and (iii) ability of endophytic fungi to interact with diverse rhizobacteria which have inorganic phosphate-solubilizing capabilities by virtue of production of a variety of organic acids and acid phosphatases (Johri et al. 2015; Meena et al. 2010; Ngwene et al. 2016; Singh et al. 2009; Srividya et al. 2009; Swetha and Padmavathi 2016). This effective P uptake in ENC plants aids in transporting absorbed phosphorus to leaves, prompting plant growth; increasing absorption of nutrients and biomass accumulation (Wu et al. 2019), consequently alleviating the adverse effects of salinity.

\section{Nitrogen}

Nitrogen plays a crucial role in cell function and metabolism (Chokshi et al. 2017). Plants absorb $\mathrm{N}$ as nitrate $\left(\mathrm{NO}_{3}{ }^{-}\right)$, ammonium $\left(\mathrm{NH}_{4}{ }^{+}\right)$ions, and also as organic compounds such as amino acids and peptides (Rentsch et al. 2007; Tegeder and Rentsch 2010) but absorption is compromised by salinity due to $\mathrm{N}$ immobilisation. Nitrate reductase (NR, E.C.1.6.6.1) catalyses reduction of $\mathrm{NO}_{3}{ }^{-}$to $\mathrm{NO}_{2}{ }^{-}$and its activity is nitrate-inducible. The $\mathrm{NR}$ activity is the limiting step in the conversion of $\mathrm{NO}_{3}{ }^{-}$to amino acids (Campbell 1999). Nitrate reductase activity in leaves is largely dependent on nitrate flux from roots (Ferrario-Méry et al. 1998) and is severely affected by osmotic stress induced by $\mathrm{NaCl}$ (Baki et al. 2000). A number of reports have shown that endophytic fungal colonization assists in $\mathrm{N}$ uptake under stress conditions (Khan et al. 2011a; Sherameti et al. 2005; Song et al. 2015). Recruitment of $\mathrm{N}$ in endophytic interactions differs from mycorrhizal interactions in which the fungus preferentially recruits ammonium rather than nitrate from the soil (Boukcim and Plassard 2003; Gage 2004). Song et al. (2015) showed that in ENC plants, $\mathrm{N}$ content increased in both the shoots and roots with increasing salt concentrations. The fungus was suggested to be involved in the cell's antioxidant and ROS-scavenging enzymes where $\mathrm{N}$ is an essential component (Cabot et al. 2014; Khan et al. 2014). Another study by Sherameti et al. (2005) showed a significant increase in growth of ENC plants that was proposed to be associated with a stimulation of the NADHdependent NR, the key enzyme of nitrate assimilation in plants.

$\mathrm{Na}^{+}: \mathrm{K}^{+}$ratio

Increased levels of $\mathrm{Na}^{+}$in cells impairs important biochemical mechanisms required for plant growth and survival. Sodium accumulation alters cellular $\mathrm{Na}^{+}: \mathrm{K}^{+}$ ratios thereby reducing the availability of $\mathrm{K}^{+}$that is required for activity of various enzymes and for the regulation of osmotic pressure and stomatal closure. Increased $\mathrm{Na}^{+}$also competes with $\mathrm{K}^{+}$, disrupting cellular metabolism in roots and leaf tissues (Abdelaziz et al. 2017). This eventually increases the $\mathrm{Na}^{+}: \mathrm{K}^{+}$ratios in the cytosol, and subsequently disrupts enzyme activity, protein synthesis, turgor maintenance, photosynthesis and stomatal movement (Evelin et al. 2019).

High $\mathrm{Na}^{+}: \mathrm{K}^{+}$ratios in plants indicate higher levels of stress. Hence, plants must maintain low levels of $\mathrm{Na}^{+}$to be able to resist the deleterious effects of salinity. ENC plants consistently have lower $\mathrm{Na}^{+}: \mathrm{K}^{+}$ratios than NENC plants under saline conditions. Reza Sabzalian and Mirlohi (2010) demonstrated that the toxic effect of $\mathrm{Na}^{+}$was mitigated in grasses inoculated with endophytic fungi by increasing $\mathrm{K}^{+}$concentration and thus maintaining the $\mathrm{Na}^{+}: \mathrm{K}^{+}$ratio in plants. Similar results were found by Song et al. (2015) and Alikhani et al. (2013) where endophytic fungi modulated ion accumulation in colonized barley plants by decreasing the foliar $\mathrm{Na}^{+}: \mathrm{K}^{+}$ ratio. Restricting the transport of $\mathrm{Na}^{+}$to leaves and ensuring a low cytosolic $\mathrm{Na}^{+}: \mathrm{K}^{+}$ratio are important ways plants can increase their tolerance to high salt levels (Berthomieu et al. 2003; Cuin et al. 2003). Increase of $\mathrm{K}^{+}$concentration is also related to mechanisms that control turgor pressure (Beckett and Hoddinott 1997). Song et al. (2015) also showed that the lower $\mathrm{Na}^{+}: \mathrm{K}^{+}$ratios observed in ENC plants decreased the level of toxic ions and osmotic influence on plants under 
salt stress. Another study on barley plants inoculated with endophytic fungi showed a decreased $\mathrm{Na}^{+}: \mathrm{K}^{+}$ratio compared to uninoculated plants, indicating that this ratio is a reliable indicator of the severity of salt stress, or for screening plant genotypes for high $\mathrm{Na}^{+}$tolerance (Ghabooli 2014) (Table 2).

Plants control $\mathrm{Na}^{+}$homeostasis through a variety of membrane proteins, antiporters, nonspecific cation channels, $\mathrm{Na}^{+}$and $\mathrm{K}^{+}$transporters, vacuolar ATPases and aquaporins, and the plasma membrane (PM) (Grabov 2007). Recently, Abdelaziz et al. (2017) postulated a molecular basis of establishing a balanced ion homeostasis of $\mathrm{Na}^{+}: \mathrm{K}^{+}$ratio in ENC plants. Inoculated Arabidopsis plants had enhanced transcript levels of the genes encoding the high Affinity Potassium Transporter 1 (HKT1) and the inward-rectifying $\mathrm{K}^{+}$channels KAT1 and KAT2, which play key roles in regulating $\mathrm{Na}^{+}$and $\mathrm{K}^{+}$homeostasis. Subsequently, lower $\mathrm{Na}^{+}: \mathrm{K}^{+}$ratios were confirmed in the Arabidopsis line gl1HKT:AtHKT 1;1 that expresses an additional AtHKT1;1 copy driven by the native promoter. This study demonstrated that endophytic colonization promotes plant growth under saline conditions by modulating the expression level of the major $\mathrm{Na}^{+}$and $\mathrm{K}^{+}$ion channels, which helps in the establishment of a balanced ion homeostasis of $\mathrm{Na}^{+}$and $\mathrm{K}^{+}$under salt stress conditions (Abdelaziz et al. 2017).

\section{Oxidative stress}

Salt stress (osmotic and ionic stress) also interferes with proper cellular functions of plants due to enhanced production of ROS, which can lead to oxidative damage in several cellular components such as lipids, proteins and DNA (Gupta and Huang 2014). ROS consist of a group of chemically reactive oxygen molecules such as hydroxyl radical (OH-), $\mathrm{H}_{2} \mathrm{O}_{2}, \mathrm{O}_{2}^{-}$and $\mathrm{O}^{2-}$ and are produced as a result of interrupted pathways in plant metabolism that cause transfer of high energy electrons to molecular oxygen (Gill and Tuteja 2010). Broad host range endophytic fungi can confer effective tolerance to ROS under abiotic stress conditions such as salinity (Mastouri et al. 2010; Rodriguez et al. 2008). (Redman et al. 2011); Singh et al. (2011) reported that exposure to high salt conditions caused ROS accumulation in tomato, rice, panic grass, and dunegrass without endophytic associations, whereas the ENC plants had decreased ROS accumulation through various pathways (Fig. 3).
Plants have two ways to counteract the adverse consequences of ROS, mainly enzymatic and nonenzymatic antioxidative systems. The enzymatic system includes catalase (CAT), ascorbate peroxidase (APX), superoxide dismutase (SOD), glutathione reductase (GR), dehydroascorbate reductases (DHAR) and monodehydroascorbate reductases (MDHAR). The non-enzymatic antioxidant system consists of ascorbic acid (AsA), glutathione (GSH), carotenoids and osmoprotectants that play roles in quenching toxic byproducts of ROS.

Baltruschat et al. (2008) reported increased activity of CAT, APX, GR and DHAR in the root tissues of barley under saline conditions. Increased activity of DHAR was seen in $P$. indica colonized barley leading to detoxification of ROS and an enhanced ratio of ascorbic acid to neutralize oxygen free radicals (Foryer and Noctor 2000). Azad and Kaminskyj (2016) used $\mathrm{H}_{2} \mathrm{O}_{2}$ localization as a proxy to assess accumulation of ROS and showed that ENC plants had lower $\mathrm{H}_{2} \mathrm{O}_{2}$ levels in their leaves following $\mathrm{NaCl}$-stress, confirming the role of endophytes to reduce stress-induced ROS generation.

Also, Zhang et al. (2016) reported that ENC plants had higher SOD, peroxidase (POD) and CAT activity suggesting that the coordination of POD and CAT activity along with SOD activity played a central protective role in the $\mathrm{O}_{2}{ }^{-}$and $\mathrm{H}_{2} \mathrm{O}_{2}$ scavenging process in ENC plants (Ahmad et al. 2015). Increased activity was a result of increased expression of the genes encoding the enzymes (Zhang et al. 2016). Under saline conditions, endophytic colonization also increases the concentrations of non-enzymatic antioxidant molecules such as AsA, GSH and carotenoids in plants as shown by several studies (Jan et al. 2019; Jogawat et al. 2013; Prasad et al. 2013; Waller et al. 2005).

Salinity increases the level of lipid peroxidation (Hernández 2019; Yu et al. 2020) which results in higher membrane permeability and loss of ions from the cells (Gupta and Huang 2014). NaCl treatment of ENC plants resulted in higher rates of lipid peroxidation in salt-sensitive plants than in salt-tolerant plants suggesting that the rate of lipid peroxidation can be used as an indicator to measure how effectively ENC plants cope with salt stress (Baltruschat et al. 2008). Another study showed that ENC plants contained higher ascorbate concentrations in roots compared with NENC plants, while the ratio of ascorbate to dehydroascorbate was not significantly altered and CAT, APX, GR, 


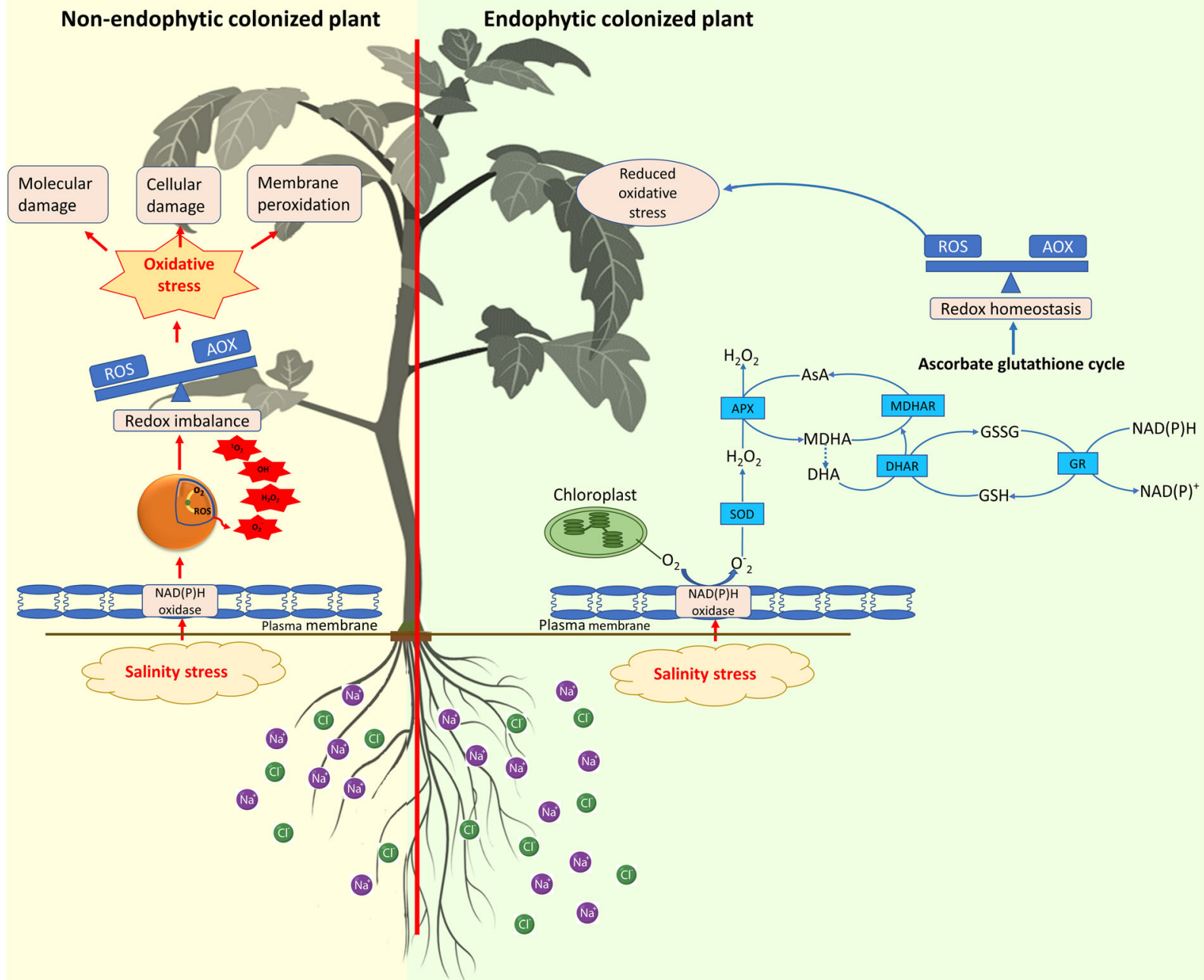

Fig. 3 Oxidative stress tolerance mechanisms in salt stressed plants. Increase in salinity causes oxidative stress in plants due to redox imbalance between ROS (reactive oxygen species) and antioxidants. This results in molecular and cellular damage and membrane peroxidation eventually disturbing the normal functioning of the cell. Several antioxidant enzymes are induced to combat salt stress including catalyse (CAT), ascorbate peroxidase (APX), superoxide dismutase (SOD), peroxidase (POX), glutathione

DHAR and MDHAR activities were increased. These changes were consistent with the decrease of leaf lipid peroxidation observed in these experiments (Waller et al. 2005). Similar results were shown by Mastouri et al. (2010) and Zhang et al. (2001) where ENC plants had significantly reduced accumulation of lipid peroxides than control plants under salt stress. Malondialdehyde (MDA), a product of lipid peroxidation, is generally regarded as an indicator of free radical damage to cell membranes caused by oxidative stress. reductase (GR), dehydroascorbate reductase (DHAR) and monodehydroascorbate reductase (MDHAR). Ascorbate (AsA), glutathione $(\mathrm{GSH})$ and carotenoids are non-enzymatic antioxidants that are produced to counteract the adverse consequences of salt stress. In endophyte colonized (ENC) plants, the tolerance mechanism in reinforced by activating an efficient antioxidant system that abates the oxidative damage caused due to salt stress

Zhang et al. (2016) reported that salt stressed ENC plants had a $15 \%$ reduction in MDA compared to salt stressed NENC plants. Table 3 lists some of the studies reporting changes in lipid compositions due to endophytic symbiosis in salt stressed plants.

\section{Photosynthesis}

Salt stress hinders photosynthesis resulting in an enormous loss in crop productivity (Sudhir and Murthy 


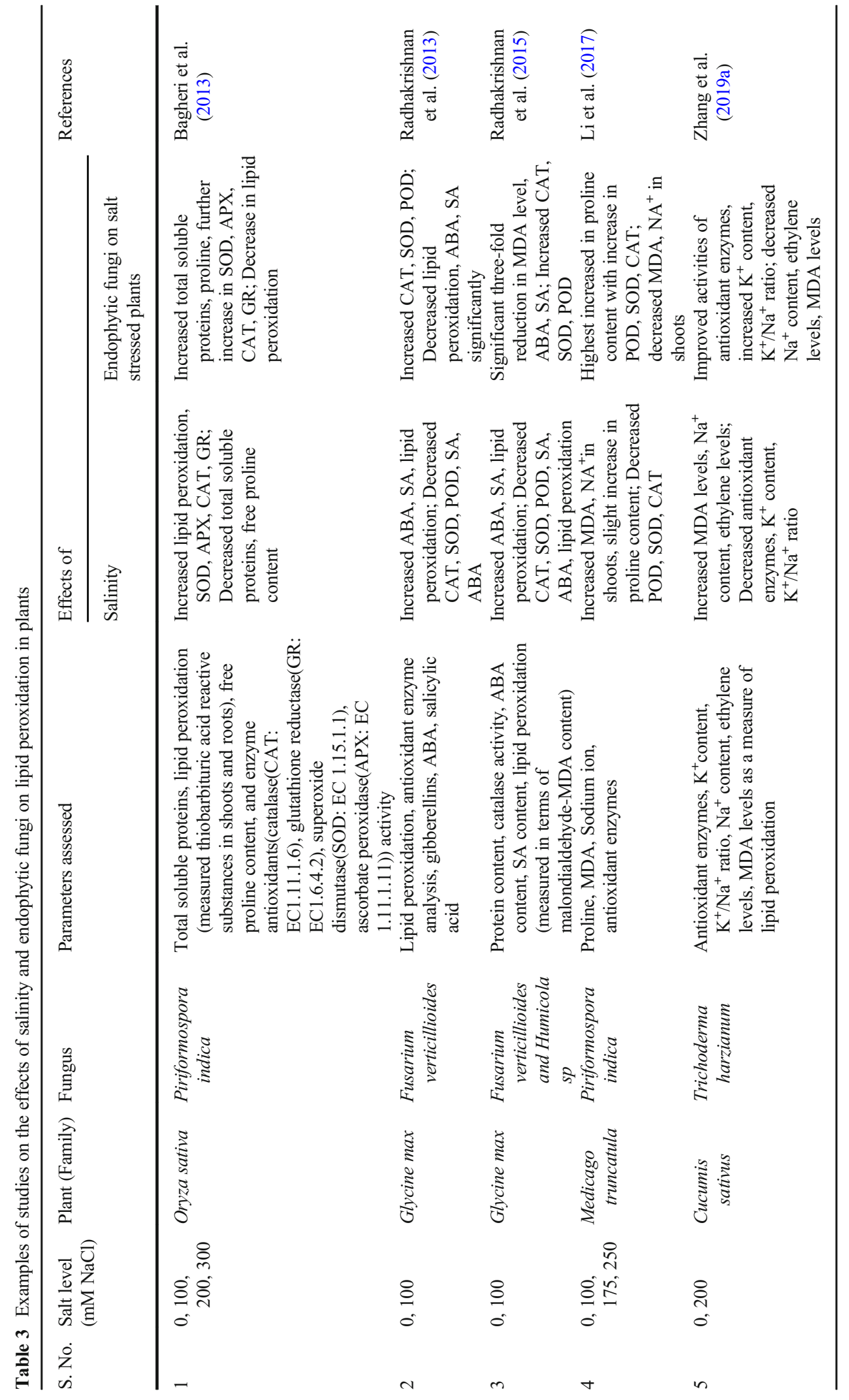


2004). Salt stress has been shown to degrade D1 and D2 proteins of the photosystem II reaction centre. These proteins play crucial roles in protein phosphorylation coupled with the flow of electrons (Jansen et al. 1996). Salt stress also results in decreased photosynthetic pigments by reducing the activity of enzymes that synthesize them. Osmotic shock resulting from salt stress leads to reduced leaf area and decrease in stomatal and mesophyll conductance (Chaves et al. 2009). This limits $\mathrm{CO}_{2}$ availability and assimilation which consequently affects RuBisCO (Seemann and Critchley 1985). Decreasing $\mathrm{CO}_{2}$ assimilation also increases the risk of the accumulation of electrons in thylakoid membranes and predisposes the photosynthetic apparatus to increased energy dissipation. Thus, to dissipate this energy, photosystem II loses excess electrons causing injury to photosynthetic tissues and affecting the net photosynthetic rate (Redondo-Gómez et al. 2010).

Plants can protect the photosystems from light induced inhibition and damage in several ways such as minimizing harvesting of light and dispersion of excess energy by non-photochemical quenching (NPQ) (Lima Neto et al. 2015). An increase in NPQ can limit quantum yield (Baker 2008) but ENC plants are reported to have lower NPQ, therefore symbiosis enhances photosynthetic efficiency by proficient conversion of harvested light into chemical energy and minimizing NPQ (Pehlivan et al. 2017). Endophytic fungi are also known to reinforce these mechanisms and reduce the negative effects of salinity on plant photosynthetic capacity (Jogawat et al. 2013; Molina-Montenegro et al. 2018). Table 4 lists some of the studies in the last decade on effect of salinity and endophytes on photosynthesis in plants. Endophytic symbiosis combats the negative effects of salt stress on photosynthesis in several ways. ENC plants have shown improved water status resulting in larger leaf area and higher stomatal conductance and eventually better assimilation of carbon dioxide (Zarea et al. 2012).

Magnesium (Mg) is one of the essential macronutrients for plant growth and is involved in numerous physiological and biochemical processes such as photosynthesis, enzyme activation and synthesis of nucleic acids ad proteins (Chen et al. 2018). It is the central atom of the tetrapyrrole ring of chlorophyll $a$ and $b$ molecules, which are the major pigments for photosynthetic light absorption (Wilkinson et al. 1990). Salt reduces uptake of $\mathrm{Mg}^{2+}$ thus also reducing the concentration of chlorophyll in leaves (Sudhir and Murthy 2004). ENC plants maintain higher chlorophyll concentration by improving the uptake of $\mathrm{Mg}^{2+}$ (Jogawat et al. 2013; Yin et al. 2014) and this leads to maintenance of plastid integrity and enhanced photosynthetic efficiency (Johnson et al. 2014).

Another way in which endophytes induce defence systems in plants under saline conditions is by upregulating the ascorbate-glutathione (ASH-GSH) cycle; for example Kumar et al. (2012) described that during salt stress, the endophytic fungus $P$. indica maintains a high antioxidative environment by defence system priming, especially the ascorbate-glutathione (ASH-GSH) cycle leading to maintenance of plastid integrity and therefore enhanced photosynthetic efficiency in colonised plants during abiotic stress (Johnson et al. 2014). ENC plants also confer the benefit of maintaining the integrity of photosystem II by repairing salt-induced degradation of D1/D2/Cytb 559 complex by the accumulation of glycine betaine in ENC plants (Rivero et al. 2014). Glycine betaine is also known to stabilise PSII pigment-protein complexes and protect the activities of $\mathrm{RuBisCO}$ and rubisco activase enzymes responsible for fixing $\mathrm{CO}_{2}$ in AM fungi (Talaat and Shawky 2014).

\section{Hormonal regulation}

Induction of phytohormones is also one of the strategies plants use to mitigate abiotic stresses that ultimately enhance plant growth and productivity in stressful environments (Ryu and Cho 2015). Phytohormones, often regarded as plant growth regulators, are compounds that are derived from plant biosynthetic pathways acting either locally or via transport to other sites within the plant to mediate growth, development and nutrient allocation (Peleg and Blumwald 2011). These include abscisic acid (ABA), gibberellins (GA), ethylene (ETHY), cytokinins (CKs), brassinosteroids (BRs) and auxins, particularly indole acetic acid (IAA). To initiate suitable plant responses to environmental stimuli, there is interplay between these hormones to modulate biochemical and physiological processes (Saeed et al. 2017).

It is known that some strains of endophytic fungi can produce plant hormones, especially gibberellins (GAs), to help the plant to tolerate or avoid abiotic stress (Contreras-Cornejo et al. 2009; Khan et al. 2011b; Waller et al. 2005). Hamayun et al. (2010) reported that inoculation with the endophytic fungi Phoma herbarum showed increased plant biomass and elevated 


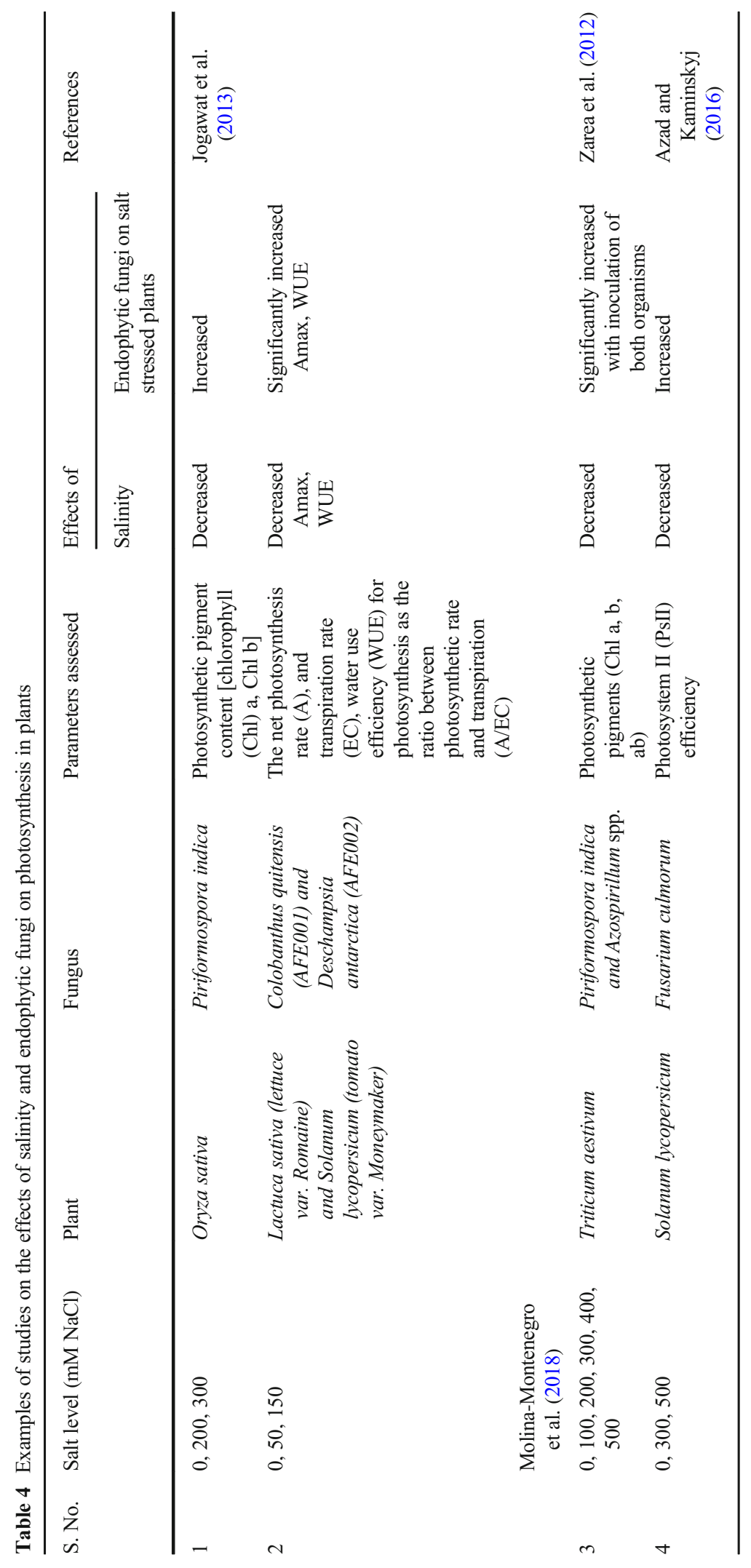


production of active GAs including $\mathrm{GA}_{1}, \mathrm{GA}_{3}, \mathrm{GA}_{4}$, and $\mathrm{GA}_{7}$ in salt-stressed soybean. Similar results were shown by Waqas et al. (2012), where salt-stressed cucumber plants inoculated with Penicillium sp. had larger shoot growth and plant biomass that was attributed to the secretion of bioactive GAs. A study on salt-stressed cucumber plants inoculated with Trichoderma asperellum Q1 alleviated the suppression effects of salt stress by altering the phytohormone levels (IAA, GA and $\mathrm{ABA}$ ) and the phosphate solubilization ability (Lei and Zhang 2015). Three bioactive GAs, i.e. $\mathrm{GA}_{4}, \mathrm{GA}_{9}$ and $\mathrm{GA}_{12}$ were more abundant in ENC plants grown under salt stress compared to NENC plants (Khan et al. 2011c), and this mitigated the adverse effects of salinity and improved growth.

Endophytic symbiosis under saline conditions has a positive influence on the endogenous concentration of auxins (Contreras-Cornejo et al. 2009). ContrerasCornejo et al. (2014) evaluated the expression of the auxin-responsive marker gene DR5:uidA which was upregulated in ENC plants compared to their counterparts under saline conditions speculating that, by providing auxins, Trichoderma spp. could restore auxin homeostasis and, consequently growth and development could be normalized when grown under salt stress.

Perspectives and future directions

Evolution has led to complex interactions between a wide diversity of microorganisms and plants; many of them resulting in the establishment of a symbiotic relationship between them (Hassani et al. 2018). These interactions beneficially impact plant survival, biodiversity, fitness and ecosystem function (Bai et al. 2018; Rosier et al. 2016; Sasse et al. 2018). Growing evidence indicates that endophytic associations can also be important for plant fitness, development of the immune system, tolerance to abiotic stresses, nutrient acquisition and disease suppression (Hiruma et al. 2016; Khan et al. 2015; Khare et al. 2018; Soliman et al. 2015; Terhonen et al. 2016; Zuccaro et al. 2014). This review highlights some of the numerous mechanisms by which endophytic symbiosis promotes salt tolerance in plants. However, there are several challenges and issues that future research should address for comprehensive understanding of these mechanisms. It is well established how osmotic adjustment in plants under salt stress via enhanced accumulation of osmolytes is achieved using endophytic symbiosis. However, the biochemical, molecular and genetic mechanisms are largely unexplored. Therefore, there is a need to understand these phenomena by investigating genes encoding enzymes used for the synthesis of molecules that are crucial for salt stress resistance. Therefore, dedicated research into unravelling the molecular basis of osmolyte accumulation in ENC plants will broaden our understanding of the mechanisms involved.

In recent years, new compounds, such as polyamines, and strigolactones have been implicated in improving plant tolerance to salt stress (Fahad et al. 2015). Strigolactones (SL) play regulatory roles to combat abiotic stress, including salinity, and in order to be fully effective, they need to modulate and interact with other phytohormones, especially auxin and ABA. SLs are also involved in several aspects of plant development; suppression of secondary branches in shoots, regulation of leaf senescence, stimulation of internode length and induction of endophytic symbiosis (de Saint Germain et al. 2013; Lopez-Raez et al. 2017; Yamada et al. 2014). This group of sesquiterpene lactones is responsible for hyphal branching and successful colonisation within roots by producing 5-deoxy-strigol, followed by the formation of a pre-penetration apparatus (Genre et al. 2005). Recently, SL secreted by roots of Arabidopsis thaliana was found to act as a signal molecule for colonization of endophytic Mucor sp. (Rozpądek et al. 2018). Studies on auxin and ABA involvement with endophytes under salt stress has been explored, but further research is required to investigate the role of strigolactones secreted by ENC plants in ameliorating salt stress.

The root is the primary location in plants that senses salt stress. The PM constitutes the interface between a cell and its surroundings and plays an important role in cell wall biosynthesis, ion transport, endocytosis, sensing of environmental stimuli, and cellular signal transduction (Mansour et al. 2015). PM lipids and proteins in salt tolerant plants are protected from oxidative attack through enhanced antioxidant systems, a mechanism that minimizes lipid and protein oxidation while retaining PM integrity (Mansour 2013). Though lipid peroxidation has been elucidated in ENC plants under salt stress, lipid metabolism in the PM in root tissues is yet to be investigated. Hence future research that evaluates how endophytic symbiosis influences these changes under saline conditions is warranted.

Limited studies are available to understand the role of endophytic fungi in modifying the photosynthetic 
capacity of plants to alleviate the negative effects of salinity as described in previous sections. Salt stress has been shown to degrade proteins of the PSII reaction centre. These proteins play fundamental roles in phosphorylation of proteins (Jansen et al. 1996). Studies in the past have focused on understanding how AMF symbiosis acts to maintain the integrity of PSII showing the upregulation of the genes encoding these proteins under salt stress (Chen et al. 2017). However, research on maintenance of these proteins by endophytic fungi under salt stress is a field to explore.

Metabolomics is increasingly being utilized for generating deep insights into abiotic stress responses. Several studies have focused on exploring and discovering compounds that stimulate ENC plant growth by alleviating stress using various technologies (Chetia et al. 2019; Kusari and Spiteller 2012; Mazlan et al. 2019; Tawfike et al. 2018). However, molecular signalling mechanisms employed by endophytic fungi under saline conditions are yet to be explored. The high-throughput mass spectrometric profiling of cellular metabolites of plant-associated endophytes under the influence of salt stress could help to reveal the level of interference by the stressor in overall cellular homeostasis. Thus, future 'omics-based research is required to generate comprehensive information on specific plant-endophytic fungisalt stress systems to resolve facts behind precise mechanisms of stress tolerance in crop plants.

Although this review covers mechanisms and strategies employed by plants under salt stress, in nature plants often face multiple biotic and abiotic stresses instead of a single stress. These combinations of stresses exert more complex effects on plant fitness which eventually results in potential differences from the responses elicited under single stresses. (Bai et al. 2018) demonstrated that tomato developed integrated responses via genetic components and cross-talk of signalling pathways under combined salinity and pathogen stresses. This shows that plants must have evolved to mitigate a combination of stresses. Addressing specific questions related to multiple stresses such as how beneficial microorganisms and pathogens or combined abiotic stresses interact would facilitate the design of strategies for sustained plant health under diverse environmental stresses.

In conclusion, directing future research on endophytic symbiosis under salinity in order to understand the above-mentioned challenges will help improve our knowledge and understanding of the mechanisms of endophyte facilitated salinity tolerance in host plants.
Acknowledgements SG thanks the University of Melbourne for providing the Melbourne Research Scholarship for financial assistance.

Open Access This article is licensed under a Creative Commons Attribution 4.0 International License, which permits use, sharing, adaptation, distribution and reproduction in any medium or format, as long as you give appropriate credit to the original author(s) and the source, provide a link to the Creative Commons licence, and indicate if changes were made. The images or other third party material in this article are included in the article's Creative Commons licence, unless indicated otherwise in a credit line to the material. If material is not included in the article's Creative Commons licence and your intended use is not permitted by statutory regulation or exceeds the permitted use, you will need to obtain permission directly from the copyright holder. To view a copy of this licence, visit http://creativecommons.org/licenses/by/4.0/.

\section{References}

Abdelaziz ME, Kim D, Ali S, Fedoroff NV, Al-Babili S (2017) The endophytic fungus Piriformospora indica enhances Arabidopsis thaliana growth and modulates $\mathrm{Na}^{+} / \mathrm{K}^{+}$homeostasis under salt stress conditions. Plant Sci 263:107-115

Abdelaziz ME, Abdelsattar M, Abdeldaym EA, Atia MA, Mahmoud AWM, Saad MM, Hirt H (2019) Piriformospora indica alters $\mathrm{Na}^{+} / \mathrm{K}^{+}$homeostasis, antioxidant enzymes and LeNHX1 expression of greenhouse tomato grown under salt stress. Sci Hort 256:108532

Ahmad P, Hashem A, Abd-Allah EF, Alqarawi AA, John R, Egamberdieva D, Gucel S (2015) Role of Trichoderma harzianum in mitigating $\mathrm{NaCl}$ stress in Indian mustard (Brassica juncea L.) through antioxidative defense system. Front Plant Sci 6:868

Alikhani M, Khatabi B, Sepehri M, Nekouei MK, Mardi M, Salekdeh GH (2013) A proteomics approach to study the molecular basis of enhanced salt tolerance in barley (Hordeum vulgare L.) conferred by the root mutualistic fungus Piriformospora indica. Mol Biosyst 9:1498-1510

Atkinson NJ, Urwin PE (2012) The interaction of plant biotic and abiotic stresses: from genes to the field. J Exp Bot 63:3523-3543

Azad K, Kaminskyj S (2016) A fungal endophyte strategy for mitigating the effect of salt and drought stress on plant growth. Symbiosis 68:73-78

Azcón-Aguilar C, Barea J (1997) Arbuscular mycorrhizas and biological control of soil-borne plant pathogens-an overview of the mechanisms involved. Mycorrhiza 6:457-464

Badri DV, Vivanco JM (2009) Regulation and function of root exudates. Plant Cell Environ 32:666-681

Bagheri AA, Saadatmand S, Niknam V, Nejadsatari T, Babaeizad V (2013) Effect of endophytic fungus, Piriformospora indica, on growth and activity of antioxidant enzymes of rice (Oryza sativa L.) under salinity stress. Int J Adv Biol Biomed Res 1:1337-1350

Bai Y, Kissoudis C, Yan Z, Visser RG, van der Linden G (2018) Plant behaviour under combined stress: tomato responses to combined salinity and pathogen stress. Plant J 93:781-793 
Bai X, Dai L, Sun H, Chen M, Sun Y (2019) Effects of moderate soil salinity on osmotic adjustment and energy strategy in soybean under drought stress. Plant Physiol Biochem 139: 307-313

Baker NR (2008) Chlorophyll fluorescence: a probe of photosynthesis in vivo. Annu Rev Plant Biol 59:89-113

Baki GAE, Siefritz F, Man HM, Weiner H, Kaldenhoff R, Kaiser W (2000) Nitrate reductase in Zea mays L. under salinity. Plant Cell Environ 23:515-521

Balliu A, Sallaku G, Rewald B (2015) AMF inoculation enhances growth and improves the nutrient uptake rates of transplanted, salt-stressed tomato seedlings. Sustainability 7:15967-15981

Baltruschat H, Fodor J, Harrach BD, Niemczyk E, Barna B, Gullner G, Janeczko A, Kogel K-H, Schäfer P, Schwarczinger I, Zuccaro A, Skoczowski A (2008) Salt tolerance of barley induced by the root endophyte Piriformospora indica is associated with a strong increase in antioxidants. New Phytol 180:501-510

Beckett R, Hoddinott N (1997) Seasonal variations in tolerance to ion leakage following desiccation in the moss Atrichum androgynum from a KwaZulu-Natal afromontane forest. S Afr J Bot 63:276-279

Bekkara F, Jay M, Viricel MR, Rome S (1998) Distribution of phenolic compounds within seed and seedlings of two Vicia faba cvs differing in their seed tannin content, and study of their seed and root phenolic exudations. Plant Soil 203:27-36

Berthomieu P, Conéjéro G, Nublat A, Brackenbury WJ, Lambert C, Savio C, Uozumi N, Oiki S, Yamada K, Cellier F, Gosti F, Simonneau T, Essah PA, Tester M, Véry A-A, Sentenac H, Casse F (2003) Functional analysis of AtHKT1 in Arabidopsis shows that $\mathrm{Na}^{+}$recirculation by the phloem is crucial for salt tolerance. EMBO J 22:2004-2014

Bertin C, Yang X, Weston LA (2003) The role of root exudates and allelochemicals in the rhizosphere. Plant Soil 256:67-83

Borowicz VA (2001) Do arbuscular mycorrhizal fungi alter plantpathogen relations? Ecology 82:3057-3068

Boukcim H, Plassard C (2003) Juvenile nitrogen uptake capacities and root architecture of two open-pollinated families of Picea abies. Effects of nitrogen source and ectomycorrhizal symbiosis. J Plant Physiol 160:1211-1218

Brimecombe MJ, De Leij FA, Lynch JM (2000) The effect of root exudates on rhizosphere microbial populations. In: Roberto P, Zeno V, Paolo N (eds) The Rhizosphere: Biochemistry and Organic Substance at the Soil-Plant Interface. Marcel Dekker, New York, pp 95-141

Brotman Y, Briff E, Viterbo A, Chet I (2008) Role of swollenin, an expansin-like protein from Trichoderma, in plant root colonization. Plant Physiol 147:779-789

Cabot C, Sibole JV, Barceló J, Poschenrieder C (2014) Lessons from crop plants struggling with salinity. Plant Sci 226:2-13

Campbell WH (1999) Nitrate reductase structure, function and regulation: bridging the gap between biochemistry and physiology. Annu Rev Plant Biol 50:277-303

Chaves M, Flexas J, Pinheiro C (2009) Photosynthesis under drought and salt stress: regulation mechanisms from whole plant to cell. Ann Bot 103:551-560

Chen TH, Murata N (2011) Glycinebetaine protects plants against abiotic stress: mechanisms and biotechnological applications. Plant Cell Environ 34:1-20
Chen L, Dick WA, Streeter JG, Hoitink HA (1998) Fe chelates from compost microorganisms improve Fe nutrition of soybean and oat. Plant Soil 200:139-147

Chen J, Zhang H, Zhang X, Tang M (2017) Arbuscular mycorrhizal symbiosis alleviates salt stress in black locust through improved photosynthesis, water status, and $\mathrm{K}^{+} / \mathrm{Na}^{+}$homeostasis. Front Plant Sci 8:1739

Chen ZC, Peng WT, Li J, Liao H (2018) Functional dissection and transport mechanism of magnesium in plants. Semin Cell Dev Biol 74:142-152

Chen T, Li C, White JF, Nan Z (2019) Effect of the fungal endophyte Epichloë bromicola on polyamines in wild barley (Hordeum brevisubulatum) under salt stress. Plant Soil 436: 29-48

Chetia KD, Bharali B. Ojha S, Barkataki MP, Saikia D, Singh T, Mosahari PV, Sharma P, Bora U (2019) Exploring the benefits of endophytic fungi via omics. In: Singh BP (ed) Advances in Endophytic Fungal Research. Springer, New York, pp 51-81

Chokshi K, Pancha I, Ghosh A, Mishra S (2017) Nitrogen starvation-induced cellular crosstalk of ROS-scavenging antioxidants and phytohormone enhanced the biofuel potential of green microalga Acutodesmus dimorphus. Biotechnol Biofuels 10:60

Contreras-Cornejo HA, Macías-Rodríguez L, Cortés-Penagos C, López-Bucio J (2009) Trichoderma virens, a plant beneficial fungus, enhances biomass production and promotes lateral root growth through an auxin-dependent mechanism in Arabidopsis. Plant Physiol 149:1579-1592

Contreras-Cornejo HA, Macías-Rodríguez L, Alfaro-Cuevas R, López-Bucio J (2014) Trichoderma spp. improve growth of Arabidopsis seedlings under salt stress through enhanced root development, osmolite production, and $\mathrm{Na}^{+}$elimination through root exudates. Mol Plant-Microbe Interact 27:503-514

Cuin TA, Miller AJ, Laurie SA, Leigh RA (2003) Potassium activities in cell compartments of salt-grown barley leaves. J Exp Bot 54:657-661

Curl EA, Truelove B (1986) The Rhizosphere. Springer-Verlag, Berlin

Dakora FD, Phillips DA (2002) Root exudates as mediators of mineral acquisition in low-nutrient environments. Plant Soil 245:35-47

de Aguilar CA-G, Azcón R, Barea J (1979) Endomycorrhizal fungi and Rhizobium as biological fertilisers for Medicago sativa in normal cultivation. Nature 279:325

de Saint Germain A, Ligerot Y, Dun EA, Pillot J-P, Ross JJ, Beveridge CA, Rameau C (2013) Strigolactones stimulate internode elongation independently of gibberellins. Plant Physiol 163:1012-1025

de Willigen P, van Noordwijk M (1987) Roots, plant production and nutrient use efficiency. PhD thesis, Wageningen University \& Research. Netherlands

dos Santos SG, da Silva PRA, Garcia AC, Zilli J, Berbara RLL (2017) Dark septate endophyte decreases stress on rice plants. Braz J Microbiol 48:333-341

Duc NH, Csintalan Z, Posta K (2018) Arbuscular mycorrhizal fungi mitigate negative effects of combined drought and heat stress on tomato plants. Plant Physiol Biochem 132:297-307

el Zahar Haichar F, Santaella C, Heulin T, Achouak W (2014) Root exudates mediated interactions belowground. Soil Biol Biochem 77:69-80 
Evelin H, Kapoor R, Giri B (2009) Arbuscular mycorrhizal fungi in alleviation of salt stress: a review. Ann Bot 104:12631280

Evelin H, Devi TS, Gupta S, Kapoor R (2019) Mitigation of salinity stress in plants by arbuscular mycorrhizal symbiosis: current understanding and new challenges. Front Plant Sci 10:470

Fahad S, Hussain S, Matloob A, Khan FA, Khaliq A, Saud S, Hassan S, Shan D, Khan F, Ullah N, Faiq M, Khan MR, Tareen AK, Khan A, Ullah A, Ullah N, Huang J (2015) Phytohormones and plant responses to salinity stress: a review. Plant Growth Regul 75:391-404

Farias GC, Nunes KG, Soares MA, de Siqueira KA, Lima WC, Neves ALR, de Lacerda CF, Filho EG (2019) Dark septate endophytic fungi mitigate the effects of salt stress on cowpea plants. Braz J Microbiol 51:243-253

Ferrario-Méry S, Valadier M-H, Foyer CH (1998) Overexpression of nitrate reductase in tobacco delays drought-induced decreases in nitrate reductase activity and mRNA. Plant Physiol 117:293-302

Foryer C, Noctor G (2000) Oxygen processing in photosynthesis: regulation and signaling. New Phytol 146:359-388

Gage DJ (2004) Infection and invasion of roots by symbiotic, nitrogen-fixing rhizobia during nodulation of temperate legumes. Microbiol Mol Biol Rev 68:280-300

Gangwar O, Singh AP (2018) Trichoderma as an efficacious bioagent for combating biotic and abiotic stresses of wheatA review. Agric Rev 39:49-54

Garcia K, Doidy J, Zimmermann SD, Wipf D, Courty P-E (2016) Take a trip through the plant and fungal transportome of mycorrhiza. Trends Plant Sci 21:937-950

Genre A, Chabaud M, Timmers T, Bonfante P, Barker DG (2005) Arbuscular mycorrhizal fungi elicit a novel intracellular apparatus in Medicago truncatula root epidermal cells before infection. Plant Cell 17:3489-3499

Gernns H, Alten H, Poehling H-M (2001) Arbuscular mycorrhiza increased the activity of a biotrophic leaf pathogen-is a compensation possible? Mycorrhiza 11:237-243

Ghabooli M (2014) Effect of Piriformospora indica inoculation on some physiological traits of barley (Hordeum vulgare) under salt stress. Chem Nat Compd 50:1082-1087

Ghaffari MR, Ghabooli M, Khatabi B, Hajirezaei MR, Schweizer P, Salekdeh GH (2016) Metabolic and transcriptional response of central metabolism affected by root endophytic fungus Piriformospora indica under salinity in barley. Plant Mol Biol 90:699-717

Gill SS, Tuteja N (2010) Reactive oxygen species and antioxidant machinery in abiotic stress tolerance in crop plants. Plant Physiol Biochem 48:909-930

Gopalakrishnan S, Sathya A, Vijayabharathi R, Varshney RK, Gowda CL, Krishnamurthy L (2015) Plant growth promoting rhizobia: challenges and opportunities. 3 Biotech 5:355-377

Grabov A (2007) Plant KT/KUP/HAK potassium transporters: single family-multiple functions. Ann Bot 99:1035-1041

Gregory PJ (2006) Roots, rhizosphere and soil: the route to a better understanding of soil science? Eur J Soil Sci 57:2-12

Gregory PJ (2007) Plant Roots: Growth, Activity and Interactions with the Soil. Blackwell, London

Groleau-Renaud V, Plantureux S, Guckert A (1998) Influence of plant morphology on root exudation of maize subjected to mechanical impedance in hydroponic conditions. Plant Soil 201:231-239

Guo L, Shi D, Wang D (2010) The key physiological response to alkali stress by the alkali-resistant halophyte Puccinellia tenuiflora is the accumulation of large quantities of organic acids and into the rhyzosphere. J Agron Crop Sci 196:123135

Gupta B, Huang B (2014) Mechanism of salinity tolerance in plants: physiological, biochemical, and molecular characterization. Int J Genomics 2014:701596-701596

Hamayun M, Khan SA, Khan AL, Rehman G, Kim Y-H, Iqbal I, Hussain J, Sohn E-Y, Lee I-J (2010) Gibberellin production and plant growth promotion from pure cultures of Cladosporium sp. MH-6 isolated from cucumber (Cucumis sativus L.). Mycologia 102:989-995

Hamayun M, Hussain A, Khan SA, Kim H-Y, Khan AL, Waqas M, Irshad M, Iqbal A, Rehman G, Jan S, Lee I-J (2017) Gibberellins producing endophytic fungus Porostereum spadiceum AGH786 rescues growth of salt affected soybean. Front Microbiol 8:686

Harman GE (2000) Myths and dogmas of biocontrol changes in perceptions derived from research on Trichoderma harzinum T-22. Plant Dis 84:377-393

Harman GE (2006) Overview of mechanisms and uses of Trichoderma spp. Phytopathology 96:190-194

Hasanuzzaman M, Nahar K, Fujita M (2013) Plant response to salt stress and role of exogenous protectants to mitigate saltinduced damages. In: Ahmad P, Azooz MM, Prasad MNV (eds) Ecophysiology and Responses of Plants under Salt Stress. Springer, New York, pp 25-87

Hasegawa PM, Bressan RA, Zhu J-K, Bohnert HJ (2000) Plant cellular and molecular responses to high salinity. Annu Rev Plant Biol 51:463-499

Hassani MA, Durán P, Hacquard S (2018) Microbial interactions within the plant holobiont. Microbiome 6:58

Hermosa R, Viterbo A, Chet I, Monte E (2012) Plant-beneficial effects of Trichoderma and of its genes. Microbiology 158: $17-25$

Hernández JA (2019) Salinity tolerance in plants: Trends and perspectives. Int J Mol Sci 20:2408

Hiltner L (1904) Uber neuere Erfahrungen und Probleme auf dem Gebiet der Boden Bakteriologie und unter besonderer Beurchsichtigung der Grundungung und Broche. Arbeit Deut Landw Ges 98:59-78

Hiruma K, Gerlach N, Sacristán S, Nakano RT, Hacquard S, Kracher B, Neumann U, Ramírez D, Bucher M, O’Connell RJ, Schulze-Lefert P (2016) Root endophyte Colletotrichum tofieldiae confers plant fitness benefits that are phosphate status dependent. Cell 165:464-474

Ho MD, Rosas JC, Brown KM, Lynch JP (2005) Root architectural tradeoffs for water and phosphorus acquisition. Funct Plant Biol 32:737-748

Jacoby R, Peukert M, Succurro A, Koprivova A, Kopriva S (2017) The role of soil microorganisms in plant mineral nutritioncurrent knowledge and future directions. Front Plant Sci 8: 1617

Jägermeyr J, Frieler K (2018) Spatial variations in crop growing seasons pivotal to reproduce global fluctuations in maize and wheat yields. Sci Adv 4:eaat4517

Jan FG, Hamayun M, Hussain A, Jan G, Iqbal A, Khan A, Lee I-J (2019) An endophytic isolate of the fungus Yarrowia 
lipolytica produces metabolites that ameliorate the negative impact of salt stress on the physiology of maize. BMC Microbiol 19:1-10

Jansen MA, Gaba V, Greenberg BM, Mattoo AK, Edelman M (1996) Low threshold levels of ultraviolet-B in a background of photosynthetically active radiation trigger rapid degradation of the D2 protein of photosystem-II. Plant J 9:693-699

Jogawat A, Saha S, Bakshi M, Dayaman V, Kumar M, Dua M, Varma A, Oelmüller R, Tuteja N, Johri AK (2013) Piriformospora indica rescues growth diminution of rice seedlings during high salt stress. Plant Signal Behav 8: e26891

Johnson JM, Alex T, Oelmüller R (2014) Piriformospora indica: the versatile and multifunctional root endophytic fungus for enhanced yield and tolerance to biotic and abiotic stress in crop plants. J Trop Agric 52:103-122

Johri AK, Oelmüller R, Dua M, Yadav V, Kumar M, Tuteja N, Varma A, Bonfante P, Persson BL, Stroud RM (2015) Fungal association and utilization of phosphate by plants: success, limitations, and future prospects. Front Microbiol 6:984

Jones DL, Nguyen C, Finlay RD (2009) Carbon flow in the rhizosphere: carbon trading at the soil-root interface. Plant Soil 321:5-33

Jung JKHM, McCouch SRM (2013) Getting to the roots of it: genetic and hormonal control of root architecture. Front Plant Sci 4:186

Kangasjärvi S, Neukermans J, Li S, Aro E-M, Noctor G (2012) Photosynthesis, photorespiration, and light signalling in defence responses. J Exp Bot 63:1619-1636

Kaur G, Asthir B (2015) Proline: a key player in plant abiotic stress tolerance. Biol Plant 59:609-619

Khan A, Geetha R, Akolkar A, Pandya A, Archana G, Desai AJ (2006) Differential cross-utilization of heterologous siderophores by nodule bacteria of Cajanus cajan and its possible role in growth under iron-limited conditions. Appl Soil Ecol 34:19-26

Khan AL, Hamayun M, Ahmad N, Hussain J, Kang S-M, Kim YH, Adnan M, Tang D-S, Waqas M, Radhakrishnan R, Hwang Y-H, Lee I-J (2011a) Salinity stress resistance offered by endophytic fungal interaction between Penicillium minioluteum LHL09 and Glycine max. L J Microbiol Biotechnol 21:893-902

Khan AL, Hamayun M, Kim Y-H, Kang S-M, Lee I-J (2011b) Ameliorative symbiosis of endophyte (Penicillium funiculosum LHL06) under salt stress elevated plant growth of Glycine max L. Plant Physiol Biochem 49:852-861

Khan AL, Hamayun M, Kim Y-H, Kang S-M, Lee J-H, Lee I-J (2011c) Gibberellins producing endophytic Aspergillus fumigatus sp. LH02 influenced endogenous phytohormonal levels, isoflavonoids production and plant growth in salinity stress. Process Biochem 46:440-447

Khan MH, Meghvansi MK, Gupta R, Veer V, Singh L, Kalita MC (2014) Foliar spray with vermiwash modifies the arbuscular mycorrhizal dependency and nutrient stoichiometry of bhut jolokia (Capsicum assamicum). PloS One 9:e92318

Khan AL, Hussain J, Al-Harrasi A, Al-Rawahi A, Lee I-J (2015) Endophytic fungi: resource for gibberellins and crop abiotic stress resistance. Crit Rev Biotechnol 35:62-74

Khare E, Mishra J, Arora NK (2018) Multifaceted interactions between endophytes and plant: developments and prospects. Front Microbiol 9:2732
Khorassani R (2008) Identification by HPLC-MS of new detected compounds in sugar beet root exudates for soil $\mathrm{P}$ mobilization. $\mathrm{PhD}$ thesis, University of Göttingen. Germany

Knapp DG, Kovács GM, Zajta E, Groenewald J, Crous PW (2015) Dark septate endophytic pleosporalean genera from semiarid areas. Persoonia 35:87-100

Kord H, Fakheri B, Ghabooli M, Solouki M, Emamjomeh A, Khatabi B, Sepehri M, Salekdeh GH, Ghaffari MR (2019) Salinity-associated microRNAs and their potential roles in mediating salt tolerance in rice colonized by the endophytic root fungus Piriformospora indica. Funct Integr Genomics 19:659-672

Kumar M, Sharma R, Jogawat A, Singh P, Dua M, Gill SS, Trivedi DK, Tuteja N, Verma AK, Oelmuller R, Johri AK (2012) Piriformospora indica, a root endophytic fungus, enhances abiotic stress tolerance of the host plant. In: Narendra T, Sarvajeet GS, Tiburcio AF, Tuteja R (eds) Improving Crop Resistance to Abiotic Stress. WileyBlackwell, Weinheim, pp 543-558

Kusari S, Spiteller M (2012) Metabolomics of endophytic fungi producing associated plant secondary metabolites: progress, challenges and opportunities. Metabolomics 10:241-266

Lei Z, Zhang Y-Q (2015) Effects of phosphate solubilization and phytohormone production of Trichoderma asperellum $\mathrm{Q} 1$ on promoting cucumber growth under salt stress. J Integr Agric 14:1588-1597

Li L, Li L, Wang X, Zhu P, Wu H, Qi S (2017) Plant growthpromoting endophyte Piriformospora indica alleviates salinity stress in Medicago truncatula. Plant Physiol Biochem 119:211-223

Li X, He X, Zhou Y, Hou Y, Zuo Y (2019) Effects of dark septate endophytes on the performance of Hedysarum scoparium under water deficit stress. Front Plant Sci 10:903

Liang W, Ma X, Wan P, Liu L (2018) Plant salt-tolerance mechanism: A review. Biochem Biophys Res Commun 495:286-291

Lima Neto MC, Martins MDO, Ferreira-Silva SL, Silveira JAG (2015) Jatropha curcasand Ricinus communis display contrasting photosynthetic mechanisms in response to environmental conditions. Sci Agr 72:260-269

Lopez-Raez JA, Shirasu K, Foo E (2017) Strigolactones in plant interactions with beneficial and detrimental organisms: the Yin and Yang. Trends Plant Sci 22:527-537

Lynch JM (1990) The Rhizosphere. Wiley, London

Machado R, Serralheiro R (2017) Soil salinity: effect on vegetable crop growth. Management practices to prevent and mitigate soil salinization. Horticulturae 3:30

Malmberg RL, Watson MB, Galloway GL, Yu W (1998) Molecular genetic analyses of plant polyamines. Crit Rev Plant Sci 17:199-224

Mansour M (2013) Plasma membrane permeability as an indicator of salt tolerance in plants. Biol Plant 57:1-10

Mansour MMF, Salama KH, Allam HY (2015) Role of the plasma membrane in saline conditions: lipids and proteins. Bot Rev $81: 416-451$

Mastouri F, Björkman T, Harman GE (2010) Seed treatment with Trichoderma harzianum alleviates biotic, abiotic, and physiological stresses in germinating seeds and seedlings. Phytopathology 100:1213-1221

Matysik J, Alia, Bhalu B, Mohanty P (2002) Molecular mechanisms of quenching of reactive oxygen species by proline under stress in plants. Curr Sci 82:525-532 
Mazlan N, Tate R, Yusoff Y, Clements C, Edrada-Ebel R (2019) Metabolomics-guided isolation of anti-trypanosomal compounds from endophytic fungi of the mangrove plant Avicennia lanata. Curr Med Chem 27:1815-1835

McNear DH Jr (2013) The rhizosphere-roots, soil and everything in between. Nat Ed Knowl 4:1

Meena KK, Mesapogu S, Kumar M, Yandigeri MS, Singh G, Saxena AK (2010) Co-inoculation of the endophytic fungus Piriformospora indica with the phosphate-solubilising bacterium Pseudomonas striata affects population dynamics and plant growth in chickpea. Biol Fert Soils 46:169-174

Meena KK, Sorty AM, Bitla UM, Choudhary K, Gupta P, Pareek A, Singh DP, Prabja R, Sahi PK, Gupta VK, Singh HB, Krishanani KK, Minhas PS (2017) Abiotic stress responses and microbe-mediated mitigation in plants: the omics strategies. Front Plant Sci 8:172

Metcalf D, Wilson C (2001) The process of antagonism of Sclerotium cepivorum in white rot affected onion roots by Trichoderma koningii. Plant Pathol 50:249-257

Minocha R, Majumdar R, Minocha SC (2014) Polyamines and abiotic stress in plants: a complex relationship1. Front Plant Sci 5:175

Molina-Montenegro MA, Acuna-Rodriguez IS, Torres-Diaz C, Gundel PE (2018) Root endophytes improve physiological performance and yield in crops under salt stress by upregulating the foliar sodium concentration. bioRxiv:435032

Morgan J, Bending G, White P (2005) Biological costs and benefits to plant-microbe interactions in the rhizosphere. $\mathrm{J}$ Exp Bot 56:1729-1739

Munns R (2005) Genes and salt tolerance: bringing them together. New Phytol 167:645-663

Munns R, Tester M (2008) Mechanisms of salinity tolerance. Annu Rev Plant Biol 59:651-681

Munns R, James RA, Lauchli A (2006) Approaches to increasing the salt tolerance of wheat and other cereals. J Exp Bot 57: $1025-1043$

Munns R, James RA, Islam A, Colmer TD (2011) Hordeum marinum-wheat amphiploids maintain higher leaf $\mathrm{K}^{+}: \mathrm{Na}^{+}$ and suffer less leaf injury than wheat parents in saline conditions. Plant Soil 348:365

Nguyen D, Rieu I, Mariani C, van Dam NM (2016) How plants handle multiple stresses: hormonal interactions underlying responses to abiotic stress and insect herbivory. Plant Mol Biol 91:727-740

Ngwene B, Boukail S, Söllner L, Franken P, Andrade-Linares D (2016) Phosphate utilization by the fungal root endophyte Piriformospora indica. Plant Soil 405:231-241

Nia SH, Zarea MJ, Rejali F, Varma A (2012) Yield and yield components of wheat as affected by salinity and inoculation with Azospirillum strains from saline or non-saline soil. J Saudi Soc Agric Sci 11:113-121

Niu YF, Chai RS, Jin GL, Wang H, Tang CX, Zhang YS (2012) Responses of root architecture development to low phosphorus availability: a review. Ann Bot 112:391-408

Oster J, Jayawardane N (1998) Agricultural management of sodic soils. In: Sumner ME, Naidu R (eds) Sodic Soils: Distribution, properties, management, and environmental consequences. Oxford University Press, New York, pp 19-34

Pang X-M, Zhang Z-Y, Wen X-P, Ban Y, Moriguchi T (2007) Polyamines, all-purpose players in response to environment stresses in plants. Plant Stress 1:173-188
Paterson E, Sim A, Standing D, Dorward M, McDonald AJS (2006) Root exudation from Hordeum vulgare in response to localized nitrate supply. J Exp Bot 57:2413-2420

Pehlivan N, Yesilyurt AM, Durmus N, Karaoglu SA (2017) Trichoderma lixii ID11D seed biopriming mitigates dose dependent salt toxicity in maize. Acta Physiol Plant 39:79

Peleg Z, Blumwald E (2011) Hormone balance and abiotic stress tolerance in crop plants. Curr Opin Plant Biol 14:290-295

Peng J, Liu J, Zhang L, Luo J, Dong H, Ma Y, Zhao X, Chen B, Sui N, Zhou Z, Meng Y (2016) Effects of soil salinity on sucrose metabolism in cotton leaves. PloS One 11:e0156241

Pinton R, Varanini Z, Nannipieri P (2007) The rhizosphere: biochemistry and organic substances at the soil-plant interface. CRC Press, Boca Raton

Prasad R, Kamal S, Sharma PK, Oelmüller R, Varma A (2013) Root endophyte Piriformospora indica DSM 11827 alters plant morphology, enhances biomass and antioxidant activity of medicinal plant Bacopa monniera. J Basic Microbiol 53: $1016-1024$

Preiss J (2018) Plant Starch Synthesis. In: Sjöö M, Nilsson L (eds) Starch in food, 2nd edn. Woodhead Publishing, Elsevier, Cambridge, pp 3-95

Qi W, Zhao L (2013) Study of the siderophore-producing Trichoderma asperellum Q1 on cucumber growth promotion under salt stress. J Basic Microbiol 53:355-364

Radhakrishnan R, Khan AL, Lee I-J (2013) Endophytic fungal pre-treatments of seeds alleviates salinity stress effects in soybean plants. J Microbiol 51:850-857

Radhakrishnan R, Khan AL, Kang SM, Lee I-J (2015) A comparative study of phosphate solubilization and the host plant growth promotion ability of Fusarium verticillioides RK01 and Humicola sp. KNU01 under salt stress. Ann Microbiol 65:585-593

Rahnama A, Munns R, Poustini K, Watt M (2011) A screening method to identify genetic variation in root growth response to a salinity gradient. J Exp Bot 62:69-77

Rawat L, Bisht T, Upadhayay R, Kukreti A (2016) Selection of salinity tolerant Trichoderma isolates and evaluating their performance in alleviating salinity stress in rice (Oryzae sativa L.). J Trop Agric 34:1869-1875

Redman RS, Kim YO, Woodward CJ, Greer C, Espino L, Doty SL, Rodriguez RJ (2011) Increased fitness of rice plants to abiotic stress via habitat adapted symbiosis: a strategy for mitigating impacts of climate change. PLOS One 6:e14823

Redondo-Gómez S, Mateos-Naranjo E, Figueroa M, Davy AJ (2010) Salt stimulation of growth and photosynthesis in an extreme halophyte, Arthrocnemum macrostachyum. Plant Biol 12:79-87

Rengasamy P (2002) Transient salinity and subsoil constraints to dryland farming in Australian sodic soils: an overview. Aust J Exp Agric 42:351-361

Rengasamy P (2006) World salinization with emphasis on Australia. J Exp Bot 57:1017-1023

Rentsch D, Schmidt S, Tegeder MJFl (2007) Transporters for uptake and allocation of organic nitrogen compounds in plants. FEBS Lett 581:2281-2289

Rewald B, Holzer L, Göransson H (2015) Arbuscular mycorrhiza inoculum reduces root respiration and improves biomass accumulation of salt-stressed Ulmus glabra seedlings. Urban For Urban Gree 14:432-437 
Reza Sabzalian M, Mirlohi A (2010) Neotyphodium endophytes trigger salt resistance in tall and meadow fescues. J Plant Nutr Soil Sci 173:952-957

Rho H, Hsieh M, Kandel SL, Cantillo J, Doty SL, Kim S-H (2018) Do endophytes promote growth of host plants under stress? A meta-analysis on plant stress mitigation by endophytes. Microb Ecol 75:407-418

Rich SM, Watt M (2013) Soil conditions and cereal root system architecture: review and considerations for linking Darwin and Weaver. J Exp Bot 64:1193-1208

Rivero RM, Mestre TC, Mittler R, Rubio F, Garcia-Sanchez F, Martinez V (2014) The combined effect of salinity and heat reveals a specific physiological, biochemical and molecular response in tomato plants. Plant Cell Environ 37:1059-1073

Robin AHK, Matthew C, Uddin MJ, Bayazid KN (2016) Salinityinduced reduction in root surface area and changes in major root and shoot traits at the phytomer level in wheat. J Exp Bot 67:3719-3729

Rodriguez RJ, Henson J, Volkenburgh EV, Hoy M, Wright L, Beckwith F, Kim Y-O, Redman RS (2008) Stress tolerance in plants via habitat-adapted symbiosis. ISME J 2:404-416

Rosier A, Bishnoi U, Lakshmanan V, Sherrier DJ, Bais HP (2016) A perspective on inter-kingdom signaling in plant-beneficial microbe interactions. Plant Mol Biol 90:537-548

Rozpądek P, Domka AM, Nosek M, Ważny R, Jędrzejczyk RJ, Wiciarz M, Turnau K (2018) The role of strigolactone in the cross-talk between Arabidopsis thaliana and the endophytic fungus Mucor sp. Front Microbiol 9:441

Ryu H, Cho Y-G (2015) Plant hormones in salt stress tolerance. J Plant Biol 58:147-155

Saddique MAB, Ali Z, Khan AS, Rana IA, Shamsi IH (2018) Inoculation with the endophyte Piriformospora indica significantly affects mechanisms involved in osmotic stress in rice. Rice 11:34

Saeed W, Naseem S, Ali Z (2017) Strigolactones biosynthesis and their role in abiotic stress resilience in plants: A critical review. Front Plant Sci 8:1487

Sallaku G, Sandén H, Babaj I, Kaciu S, Balliu A, Rewald BJ (2019) Specific nutrient absorption rates of transplanted cucumber seedlings are highly related to RGR and influenced by grafting method, AMF inoculation and salinity. Sci Hortic 243:177-188

Salope-Sondi B, Pollmann S, Gruden K, Oelmüller R, LudwigMüller J (2015) Improvement of root architecture under abiotic stress through control of auxin homeostasis in Arabidopsis and Brassica crops. Endocytobiosis Cell Res 26:100-111

Samolski I, Rincon AM, Pinzón LM, Viterbo A, Monte E (2012) The qid74 gene from Trichoderma harzianum has a role in root architecture and plant biofertilization. Microbiol 158: $129-138$

Sasse J, Martinoia E, Northen T (2018) Feed your friends: do plant exudates shape the root microbiome? Trends Plant Sci 23: $25-41$

Seemann JR, Critchley C (1985) Effects of salt stress on the growth, ion content, stomatal behaviour and photosynthetic capacity of a salt-sensitive species. Phaseolus vulgaris L Planta 164:151-162

Shahbaz M, Ashraf M (2013) Improving salinity tolerance in cereals. Crit Rev Plant Sci 32:237-249
Shelden MC, Dias DA, Jayasinghe NS, Bacic A, Roessner U (2016) Root spatial metabolite profiling of two genotypes of barley (Hordeum vulgare L.) reveals differences in response to short-term salt stress. J Exp Bot 67:3731-3745

Sherameti I, Shahollari B, Venus Y, Altschmied L, Varma A, Oelmüller R (2005) The endophytic fungus Piriformospora indica stimulates the expression of nitrate reductase and the starch-degrading enzyme glucan-water dikinase in tobacco and Arabidopsis roots through a homeodomain transcription factor that binds to a conserved motif in their promoters. $\mathrm{J}$ Biol Chem 280:26241-26247

Shrivastava P, Kumar R (2015) Soil salinity: A serious environmental issue and plant growth promoting bacteria as one of the tools for its alleviation. Saudi J Biol Sci 22:123-131

Singh R (2014) Microorganism as a tool of bioremediation technology for cleaning environment: a review. Proc Int Acad Ecol Environ Sci 4:1

Singh G, Singh N, Marwaha T (2009) Crop genotype and a novel symbiotic fungus influences the root endophytic colonization potential of plant growth promoting rhizobacteria. Physiol Mol Biol Plants 15:87-92

Singh LP, Gill SS, Tuteja N (2011) Unraveling the role of fungal symbionts in plant abiotic stress tolerance. Plant Signal Behav 6:175-191

Singh P, Basu S, Kumar G (2018) Polyamines metabolism: A way ahead for abiotic stress tolerance in crop plants. In: Wani S H (ed) Biochemical, physiological and molecular avenues for combating abiotic stress tolerance in plants. Elsevier, pp 39-55

Smith PA (2014) Foliage friendships. Sci Am 311:24-25

Smith SE, Smith FA (2011) Roles of arbuscular mycorrhizas in plant nutrition and growth: new paradigms from cellular to ecosystem scales. Annu Rev Plant Biol 62:227-250

Soliman SS, Greenwood JS, Bombarely A, Mueller LA, Tsao R, Mosser DD, Raizada MN (2015) An endophyte constructs fungicide-containing extracellular barriers for its host plant. Curr Biol 25:2570-2576

Song M, Chai Q, Li X, Yao X, Li C, Christensen MJ, Nan Z (2015) An asexual Epichloë endophyte modifies the nutrient stoichiometry of wild barley (Hordeum brevisubulatum) under salt stress. Plant Soil 387:153-165

Srividya S, Soumya S, Pooja K (2009) Influence of environmental factors and salinity on phosphate solubilization by a newly isolated Aspergillus niger F7 from agricultural soil. Afr J Biotechnol 8:1864-1870

Steffen W, Burbidge AA, Hughes L, Kitching R, Lindenmeyer D, Musgrave W, Smith MS, Werner PA (2009) Australia's biodiversity and climate change. CSIRO Publishing, Collingwood

Sudhir P, Murthy S (2004) Effects of salt stress on basic processes of photosynthesis. Photosynthetica 42:481-486

Sun C, Lu L, Liu L, Liu W, Yu Y, Liu X, Hu Y, Jin C, Lin X (2014) Nitrate reductase-mediated early nitric oxide burst alleviates oxidative damage induced by aluminum through enhancement of antioxidant defenses in roots of wheat (Triticum aestivum). New Phytol 201:1240-1250

Swetha S, Padmavathi T (2016) Study of acid phosphatase in solubilization of inorganic phosphates by Piriformospora indica. Polish J Microbiol 65:407-412

Talaat NB, Shawky BT (2014) Protective effects of arbuscular mycorrhizal fungi on wheat (Triticum aestivum L.) plants exposed to salinity. Environ Exp Bot 98:20-31 
Tawfike AF, Abbott G, Young L, Edrada-Ebel R (2018) Metabolomic-guided isolation of bioactive natural products from Curvularia sp., an endophytic fungus of Terminalia laxiflora. Planta Med 84:182-190

Tegeder M, Rentsch D (2010) Uptake and partitioning of amino acids and peptides. Mol Plant 3:997-1011

Terhonen E, Sipari N, Asiegbu FO (2016) Inhibition of phytopathogens by fungal root endophytes of Norway spruce. Biol Control 99:53-63

Thrane C, Tronsmo A, Jensen DF (1997) Endo-1, 3- $\beta$-glucanase and cellulase from Trichoderma harzianum: purification and partial characterization, induction of and biological activity against plant pathogenic Pythium spp. Eur J Plant Pathol 103: 331-344

Todorova D, Katerova Z, Sergiev I, Alexieva V (2013) Role of polyamines in alleviating salt stress. In: Ahmad P, Azooz MM, Prasad MNV (eds) Ecophysiology and Responses of Plants under Salt Stress, vol 13. Springer, New York, pp 355-379

Uchida R (2000) Essential nutrients for plant growth: nutrient functions and deficiency symptoms. In: Silva JA, Uchida R (eds) Plant Nutrient Management in Hawaii's Soils. University of Hawaii Press, Honolulu, pp 31-55

Udvardi M, Poole PS (2013) Transport and metabolism in legumerhizobia symbioses. Annu Rev Plant Biol 64:781-805

Uma Shaanker R (2014) Evaluation of endophytic fungal assemblages of salt adapted paddy varieties and their role in imparting salinity tolerance. $\mathrm{PhD}$ thesis, University of Agricultural Sciences. Bangalore

Uren NC (2000) Types, amounts, and possible functions of compounds released into the rhizosphere by soil-grown plants. In: Roberto P, Zeno V, Paolo N (eds) The Rhizosphere Biochemistry and Organic Substances at the Soil-Plant Interface. Marcel Dekker, New York, pp 19-40

Vahabi K, Dorcheh SK, Monajembashi S, Westermann M, Reichelt M, Falkenberg D, Hemmerich P, Sherameti I, Oelmüller R (2016) Stress promotes ArabidopsisPiriformospora indica interaction. Plant Signal Behav 11: e1136763

Viterbo A, Harel M, Chet I (2004) Isolation of two aspartyl proteases from Trichoderma asperellum expressed during colonization of cucumber roots. FEMS Microbiol Lett 238: 151-158

Waller F, Achatz B, Baltruschat H, Fodor J, Becker K, Fischer M, Heier T, Hückelhoven R, Neumann C, von Wittstein D, Franken P, Kogel K-H (2005) The endophytic fungus Piriformospora indica reprograms barley to salt-stress tolerance, disease resistance, and higher yield. PNAS 102:1338613391

Wani SH (2018) Biochemical, Physiological and Molecular Avenues for Combating Abiotic Stress in Plants. Elsevier, London

Waqas M, Khan AL, Kamran M, Hamayun M, Kang S-M, Kim Y-H, Lee I-J (2012) Endophytic fungi produce gibberellins and indoleacetic acid and promotes host-plant growth during stress. Molecules 17:10754-10773

Watt M (2009) The rhizosphere: biochemistry and organic substances at the soil-plant interface. Ann Bot 104:9-10

Watt M, Evans JR (1999) Linking development and determinacy with organic acid efflux from proteoid roots of white lupin grown with low phosphorus and ambient or elevated atmospheric $\mathrm{CO}_{2}$ concentration. Plant Physiol 120:705-716

Wilkinson SR, Welch RM, Mayland HF, Grunes DL (1990) Magnesium in plants: uptake, distribution, function, and utilization by man and animals. In: Sigel $\mathrm{H}$ (ed) Metal Ions in Biological Systems, vol 26. Marcel Dekker, New York, pp $33-56$

Williams K (1997) Interactions of polyamines with ion channels. Biochem J 325:289-297

Wu C, Li B, Wei Q, Pan R, Zhang W (2019) Endophytic fungus Serendipita indica increased nutrition absorption and biomass accumulation in Cunninghamia lanceolata seedlings under low phosphate. Acta Ecol Sin 39:21-29

Yamada Y, Furusawa S, Nagasaka S, Shimomura K, Yamaguchi S, Umehara M (2014) Strigolactone signaling regulates rice leaf senescence in response to a phosphate deficiency. Planta 240:399-408

Yang B, Wang X, Ma H, Yang T, Jia Y, Zhou J, Dai C (2015) Fungal endophyte Phomopsis liquidambari affects nitrogen transformation processes and related microorganisms in the rice rhizosphere. Front Microbiol 6:982

Yasmeen T, Tariq M, Iqbal S, Arif MS, Riaz M, Shahbad SM, Ali S, Noman M, Li T (2019) Ameliorative capability of plant growth promoting rhizobacteria (PGPR) and arbuscular mycorrhizal fungi (AMF) against salt stress in plants. In: Hasanuzzaman M, Khalid RH, Kamrun N, Hesham FA (eds) Plant Abiotic Stress Tolerance Agronomic, Molecular and Biotechnological Approaches. Springer, Switzerland, pp 409-448

Yedidia I, Benhamou N, Chet I (1999) Induction of defense responses in cucumber plants (Cucumis sativus L.) by the biocontrol agent Trichoderma harzianum. Appl Environ Microbiol 65:1061-1070

Yin L, Ren A, Wei M, Wu L, Zhou Y, Li X, Gao Y (2014) Neotyphodium coenophialum-infected tall fescue and its potential application in the phytoremediation of saline soils. Int J Phytoremediation 16:235-246

Yu D, Boughton BA, Hill C, Feussner I, Roessner U, Rupasinghe TWT (2020) Insights into oxidized lipid modification in barley roots as an adaptation mechanism to salinity stress. Front Plant Sci 11:1

Yuan Z-1, Su Z-Z, Zhang C-1 (2016) Understanding the biodiversity and functions of root fungal endophytes: The Ascomycete Harpophora oryzae as a model case. In: Druzhinina IS, Kubicek CP (eds) Environmental and Microbial Relationships. Springer, Berlin, pp 205-214

Yun P, Xu L, Wang S-S, Shabala L, Shabala S, Zhang W-Y (2018) Piriformospora indica improves salinity stress tolerance in Zea mays L. plants by regulating $\mathrm{Na}^{+}$and $\mathrm{K}^{+}$loading in root and allocating $\mathrm{K}^{+}$in shoots. Plant Growth Regul 86: 323-331

Zarea M, Hajinia S, Karimi N, Goltapeh EM, Rejali F, Varma A (2012) Effect of Piriformospora indica and Azospirillum strains from saline or non-saline soil on mitigation of the effects of $\mathrm{NaCl}$. Soil Biol Biochem 45:139-146

Zhang H-X, Hodson JN, Williams JP, Blumwald E (2001) Engineering salt-tolerant Brassica plants: characterization of yield and seed oil quality in transgenic plants with increased vacuolar sodium accumulation. PNAS 98:12832-12836

Zhang F, Meng X, Yang X, Ran W, Shen Q (2014) Quantification and role of organic acids in cucumber root exudates in 
Trichoderma harzianum T-E5 colonization. Plant Physiol Biochem 83:250-257

Zhang S, Gan Y, Xu B (2016) Application of plant-growthpromoting fungi Trichoderma longibrachiatum T6 enhances tolerance of wheat to salt stress through improvement of antioxidative defense system and gene expression. Front Plant Sci 7:1405

Zhang R, Vivanco JM, Shen Q (2017a) The unseen rhizosphere root-soil-microbe interactions for crop production. Curr Opin Microbiol 37:8-14

Zhang W, Wang X-X, Yang Z, Ashaduzzaman SM, Kong M-J, Lu L-Y, Shen J-X, Dai C-C (2017b) Physiological mechanisms behind endophytic fungus Phomopsis liquidambari-mediated symbiosis enhancement of peanut in a monocropping system. Plant Soil 416:325-342

Zhang F, Wang Y, Liu C, Chen F, Ge H, Tian F, Yang T, Ma K, Zhang Y (2019a) Trichoderma harzianum mitigates salt stress in cucumber via multiple responses. Ecotoxicol Environ Saf 170:436-445

Zhang S, Gan Y, Xu B (2019b) Mechanisms of the IAA and ACCdeaminase producing strain of Trichoderma longibrachiatum $\mathrm{T} 6$ in enhancing wheat seedling tolerance to $\mathrm{NaCl}$ stress. BMC Plant Biol 19:22

Zhao L, Wang F, Zhang Y, Zhang J (2014) Involvement of Trichoderma asperellum strain T6 in regulating iron acquisition in plants. J Basic Microbiol 54:S115-S124

Zuccaro A, Lahrmann U, Langen G (2014) Broad compatibility in fungal root symbioses. Curr Opin Plant Biol 20:135-145

Publisher's Note Springer Nature remains neutral with regard to jurisdictional claims in published maps and institutional affiliations. 